\title{
اشتراط دورة تأهيلية للمقبلين على الزواج في فلسطين: المشروعية والحاجة
}

\author{
يوسف عطية حسن كليبي \\ الاستاذ المساعد في قسم القضاء الشرعي- كلية الدعوة الإسلامية- قلقيلية \\ yoseufk@hotmail.com
}

اهتم الإسلام بالأسرة والزواج وأعلى من شأهما، وشرع كل ما يعمل على صون وتوثيق رابطهما، وشرع طريقاً لانحلال

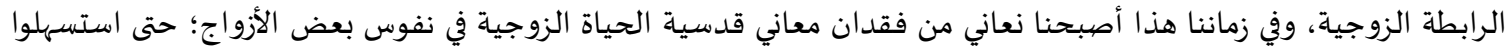

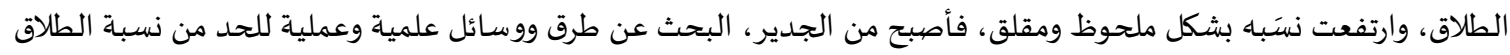

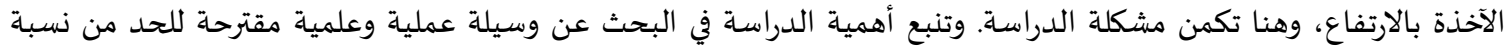

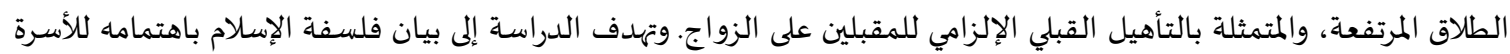

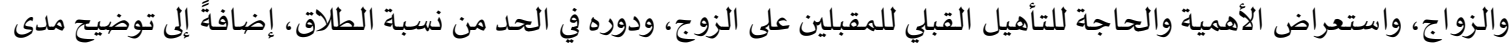

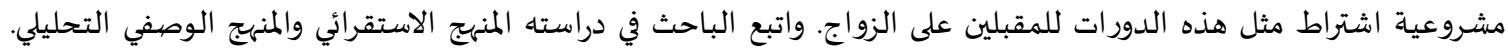

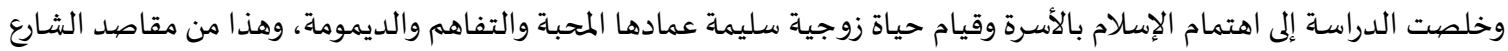

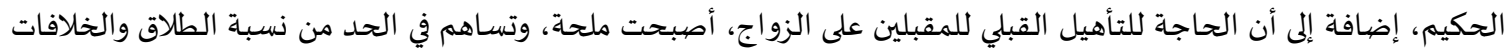

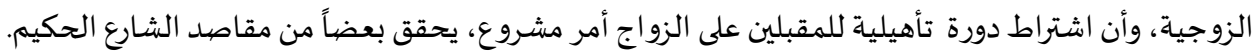

كلمات مفتاحية: الزواج، الطلاق، الدورات، التأهيل، فلسطين.

\section{(9) (1)}

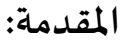

لقد أولى الإسلام الأسرة أهمية كبيرة؛ لما تمثله الأسرة من أهمية تعود على الفرد والمجتمع بأسره، وتكوين الأسرة أمر فطري

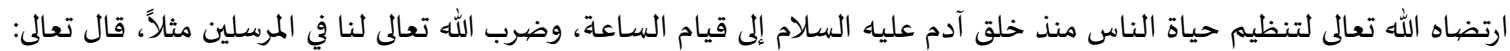

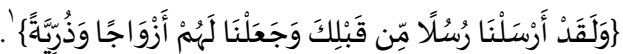

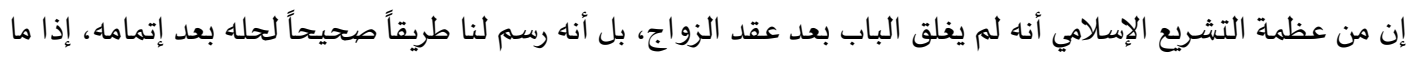

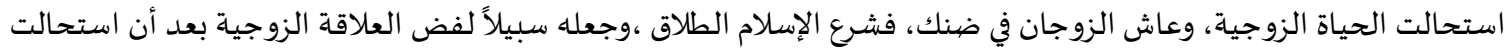



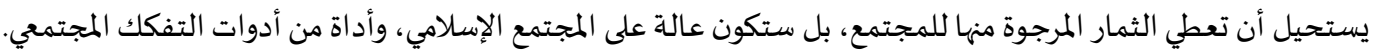

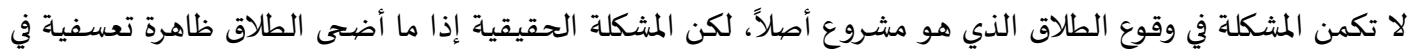

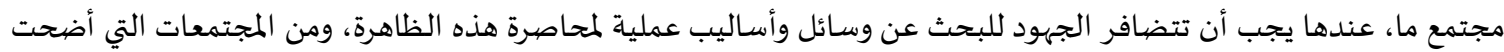

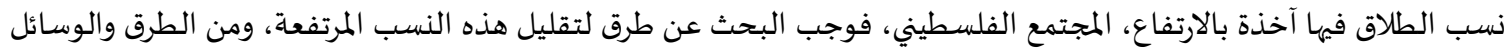

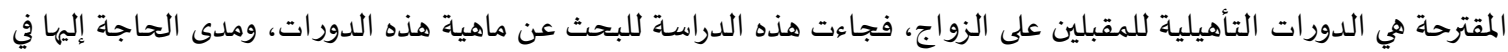
المجتمع الفلسطيني، ومشروعية اشتراطها للمقبلين على الزواج. 


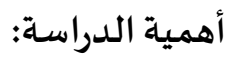

تنبع أهمية هذه الدراسة من خلال الأهمية التي حظيت بها الأسرة في التشريع الإسلامي، ومن الأهمية التي أولاها الإسلام لعقد

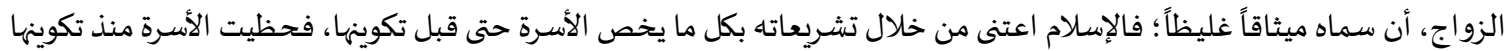

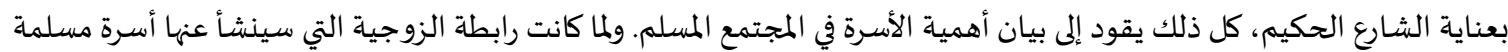
بهذه الأهمية، فإن للعقل المسلم أن يبتكر ويستكشف الوسائل التي من شأنها تعميق هذه الرابطة وحفظها من الانهيار والتفكك، ولمات الماتيا

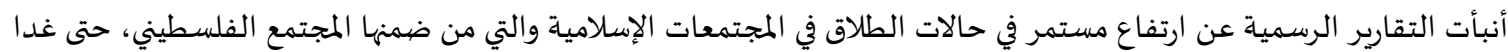

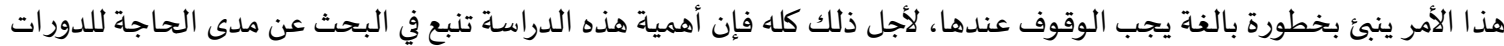

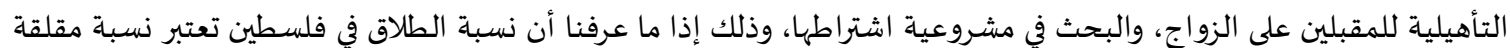
ومتزايدة، فتكون أهمية هذه الدراسة بتسليط الضوء على وسيلة عملية بغية محاصرة هذا الأمر المقلق حتى لا يغدو ظاهرة

مستفحلة. وأخيراً فإن من أهمية هذه الدراسة هو الخروج عن الإطار النظري البحت، ومحاولة ملامسة مشكلات مجتمع بأسره، والبحث عن حلول عملية الى جانب الاطار النظري، وذلك من خلال البحث في أهمية التأهيل القبلي والحاجة إليها

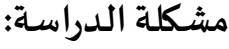

تدور مشكلة الدراسة حول ارتفاع نسب الطلاق في فلسطين خصوصاً بين الأزواج الشابة، حتى باتت هذه الظاهرة حالة

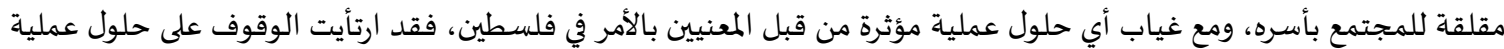
قابلة للتطبيق في الأراضي الفلسطينية. فالمشكلة لا تكمن في وقوع الطلاق، فهو أمر لا مفر منه، وجعله الشارع الحكيم طريقاً شرعياً لفض العلاقة الزوجية إذا ما

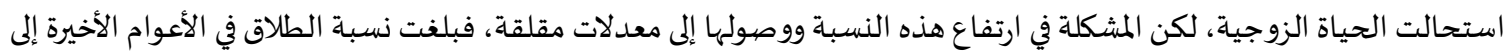

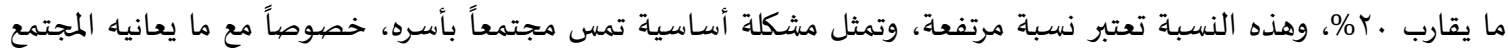

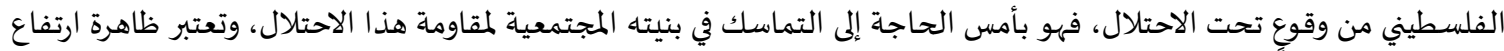
نسبة الطلاق ظاهرة خطيرة تمس المجتمع بأسرة، ذلك لأن السلم الأسري أحد مقومات السلم المجتمعي.

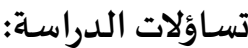

مهدف الباحث من خلال دراسته الإجابة عن الأسئلة الآتية:

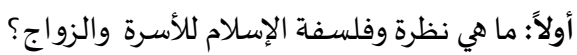

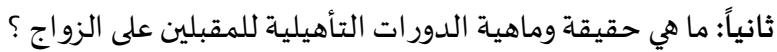

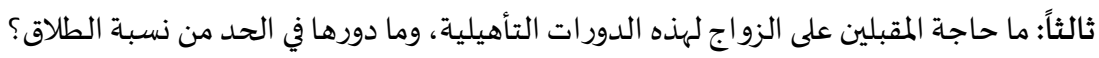

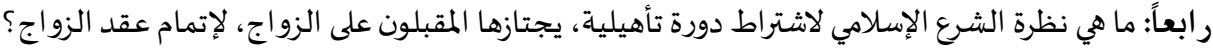

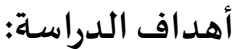

يهدف الباحث من خلال دراسة موضوع "اشتراط دورة تأهيلية للمقبلين على الزواج في فلسطين: المشروعية والحاجة" إلى الى الماني تحقيق مجموعة من الأهداف، وذلك على النحو الآلتي: أولاً: بيان نظرة الشرع الإسلامي للأسرة والزواج، وفلسفتاه تجاههما بإحاطتهما بمجموعة من الأحكام التي تضمن ديمومتهما، وجعل الأسرة لبنة صالحة في المجتمع الإنلامي. ثانياً: توضيح حقيقة وماهية الدورة التأهيلية للمقبلين على الزئية الزواج. ثالثاً: استعراض الحاجة لهذه الدورة، وما يمكن أن تقدمه على صعيد تثقيف الشباب المقبل على الزواج، وعلاقتها بتخطي المشكلات والحد من نسبة الطلاق في المجتمع الفلسطيني. رابعاً: بيان مدى توافق وتعارض استحداث شروط يجب لماف أن يتمها ويتحصل عليها من يريد الإقدام على الزواج مع أحكام الشرع الإسلامي وروحه. - المان. 
منهج الدراسـة:

اتبعت الدراسة المنهج الاستقرائي والوصفي التحليلي، حيث تتبعت كل ما له علاقة بموضوع البحث، ثم عمدت إلى وصف الته

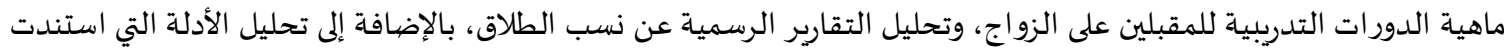
إليها في الترجيح.

الدراسات السابقة:

مما لا شك فيه أن الدراسات التي تناولت موضهوع الزواج والطلاق كثيرة جداً، ولكن الدراسات التي بحثت في فاعلية الدورات التدريبية للمقبلين على الزواج ما زالت قليلة نسبياً، ومن هذه الدراسات:

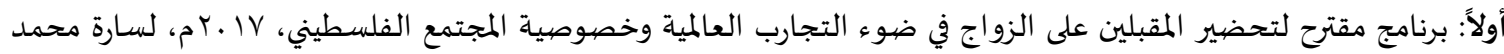

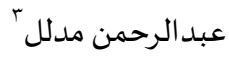
رسالة ماجستير في دراسات المرأة، ذكرت الباحثة أن الدافع وراء دراستها هو الارتفاع الملحوظ في معدلات الطلاق في فلسطين،

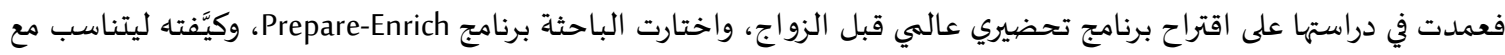
خصوصية المجتمع الفلسطيني، وقدمت الباحثة آلية تقديم هذا البرنامج وميزاتها.

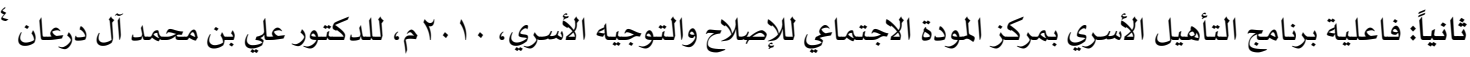
دراسة استطلاعية قام بها الدكتور علي بن محمد آل درعان لصالح مركز المودة الاجتماعي للإصلاح والتوجياه الأسري

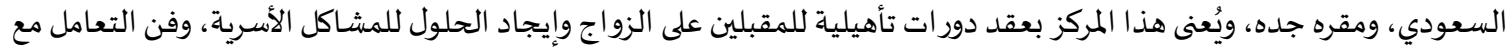
الزوجة والأبناء والمراهقين، وكل ما لله علاقة بالأسرة، وتهدف هذه الدراسة لتقييم فاعلية البرنامج التدريبي الذي يعقده المركز للمقبلين على الزواج في إيجاد حالة زوجية إيجابية، والتغلب على المشكلات، وتقييم المستفيدين للسنة الأولى من حياتهم الزوجياة،

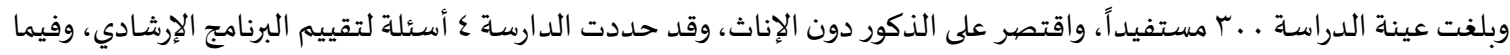

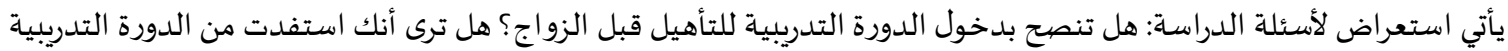

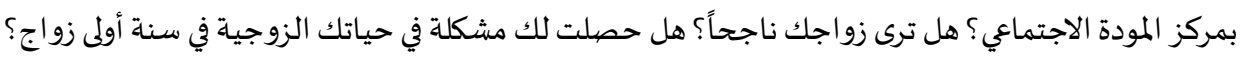

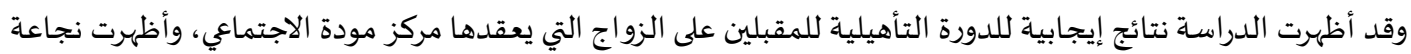

هذا البرنامج في الحد من نسبة المشاكل الزوجية.

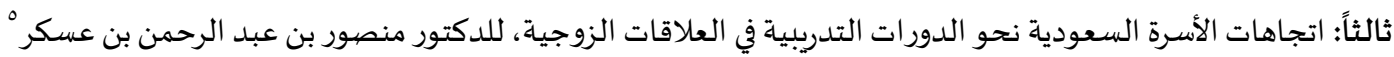

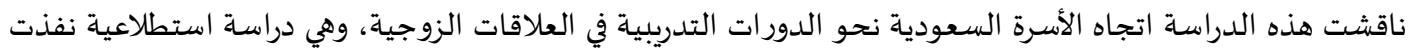

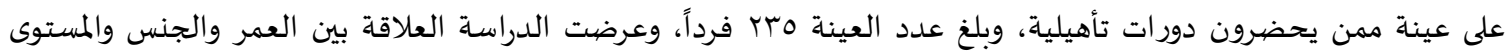

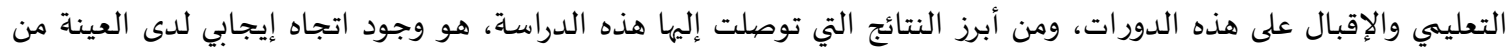

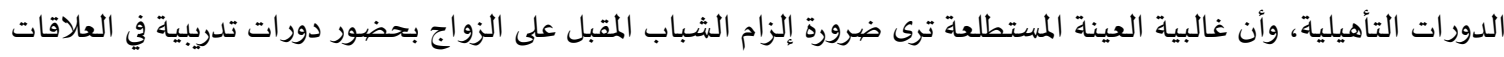
الزوجياة، وأن هذه الدورات ستساهم في تخفيف المشكلات الأسرية. رابعاً: دور برامج التأهيل في التوعية بالتخطيط للزواج وبناء الأسرة دراسة وصفية تحليلية لبرامج التأهيل للزواج والمستفيدين منها بمدينة جدة

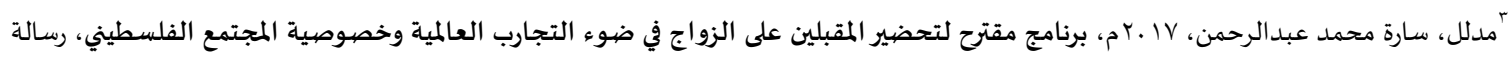

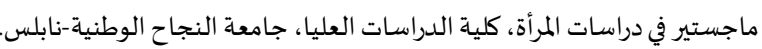

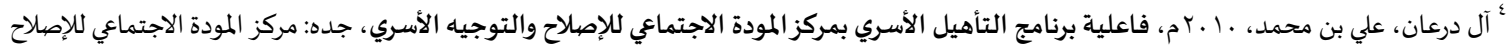
والتوجياء الأسري. أبن عسكر، منصور بن عبد الرحمن، (د.ت)، اتجاهات الأسرة السعودية نحو الدورات التدريبية في العلاقات الزوجية، السعودية: مشروع ابن باز الخيري لمساعدة الشباب على الزواج، مركز المعلومات وأبحاث الأسرة.

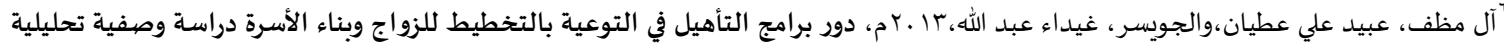

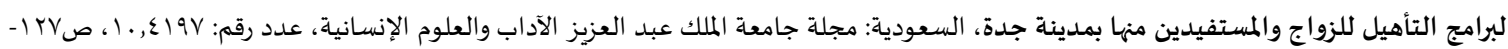


مقال علمي منشور، هدف إلى التعرف واستعراض البرامج التأهيلية التي تقدمها ثلاثة مراكز خيرية متواجدة في جدة، حيث

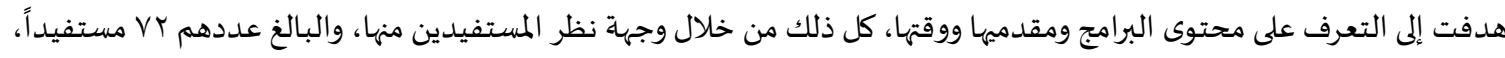

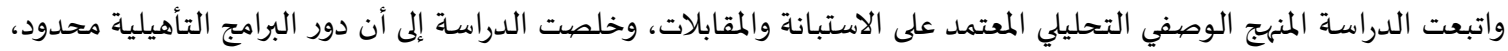

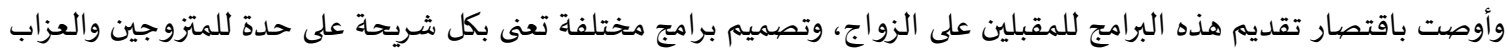
والآباء والمطلقين والأرامل.

يتضح من خلال استعراض الدراسات السابقة ما يأتي: أغلب الدراسات جاءت لتقييم فاعلية الدورات التأهيلية من أشخاص مستفيدين من هذه الدورات، وأغلهها استهدفت المتزوجين فعلياً، وليس المقبلين على الزواج.

أظهرت الدراسات وجود توجاه إيجابي لهذه الدورات من قبل المستفيدين منها، وإن لها أثر في تحسين العلاقة الزوجية وتجاوز

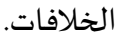

أغلب الدراسات عملت على بيان فاعلية هذه الدورات في المملكة السعودية، ويرجع هذا الأمر إلى ارتفاع حالات الطلاق في

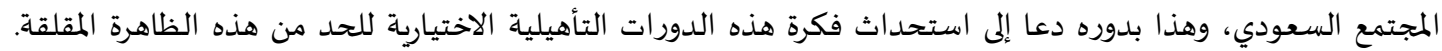
ونتيجة لارتفاع معدلات الطلاق في المجتمع العربي عامة، فإن بعض الدراسات قامت باستحداث برنامج إرشادي للمتزوجين مئن

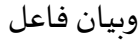

إضـافة الدراسـة الحالية

لقد جاءت هذه الدراسة لتبني على ما جاء في الدراسات السابقة، وقد اهتم الباحث بعدة جوانب لم تستعرضها الدراسـات

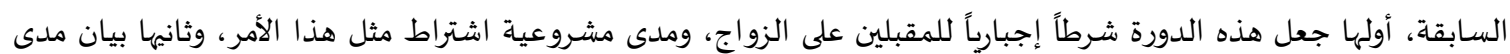

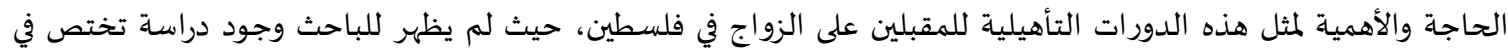
فلسطين بهذا الجانب، إضافة إلى أن الباحث لم يقع على دراسة تبحث في مشروعية اشتراط مثل هذه الدورات للمقبلين على الزواج، وجعلها شرطاً لإتمام عقد الزو اج.

\section{المبحث الأول: فلسفة الإسلام للأسرة والزواج والطلاق}

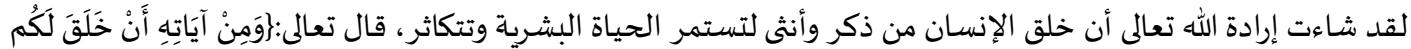

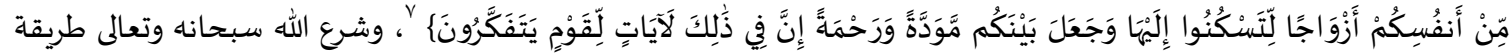
واحدة لكي يتم اللقاء بين هذين الجنسين؛ ليعمر هذا الكون، فأقَّر التزاوج ليكون اللبنة الأولى نحو تكوين أول أسـاس من أسـاسات بناء المجتمع؛ وهو الأسرة.

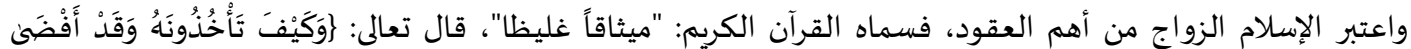

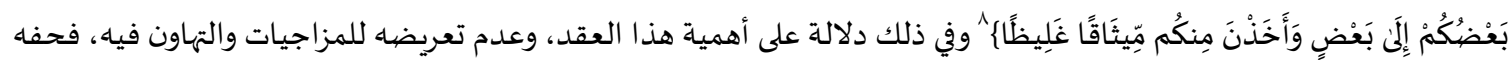
بشروط ضامنة لاستمراره وتعظيمه في النفس أكثر من العقود المالية الأخرى؛ لتعلقه بالنفوس التي كرمها الله تعالى على سائر

مخلوقاته جميعاً.

لا يهدف الإسلام من الزواج إلى تقنين العملية الجنسية بين الجنسين فحسب، بل إن الإسلام أراد من الزواج أن يكون

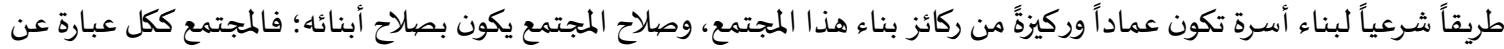

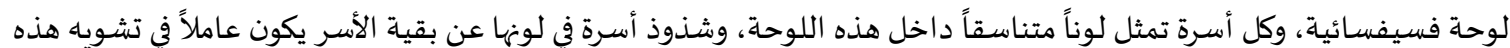

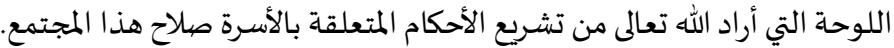
إن عقد الزواج وما يكتنفه من شروط وضعها الشارع الحكيم إنما يهدف من ذلك إلى تكوين أسرة مبنية على أسس سله سليمة، تتوفر لها كل مقومات الاستمرارية، وجاءت هذه الشروط للسمو بالعلاقة بين الذكر والأنثى عن الحيوانات التي يكون جل اهتمامهما

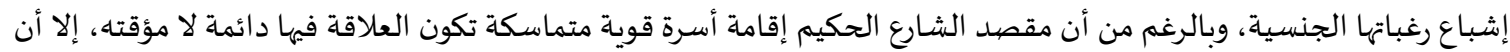

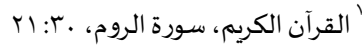

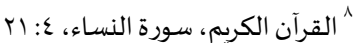

المجلة الدولية للدراسات الإسلامية المتخصصية _ المجلدr ، العدد ا - 19 ب r 


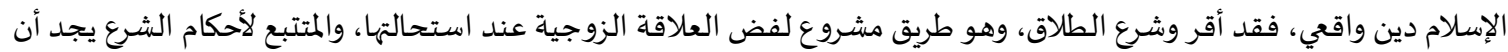

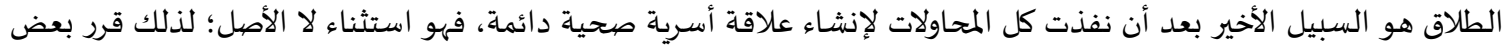

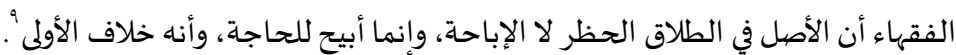

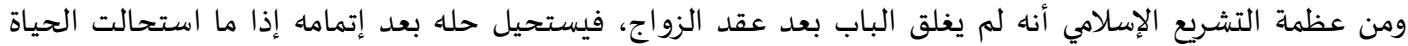

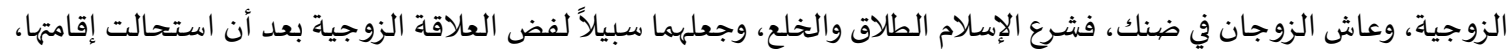

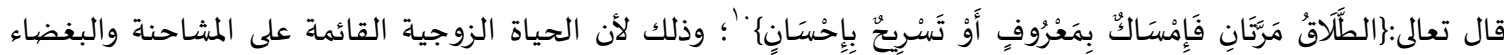

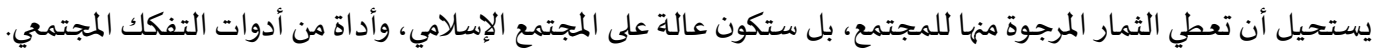

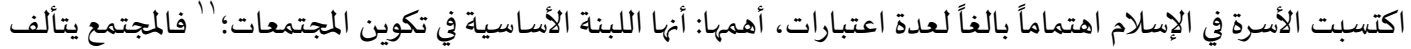

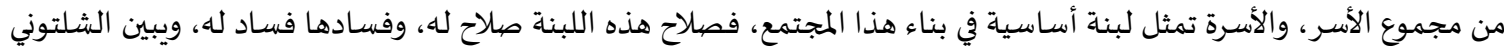

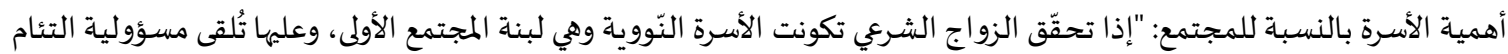

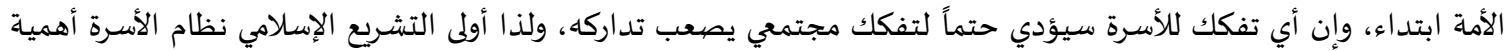

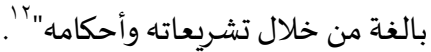
ذكرت فتحية توفيق العلاقة بين صلاح الأسرة وصلاح المجتمع، وبين تفككها وأثر ذلك على المجتمع: "اللَّنةٌُ الأولى في بناء أي

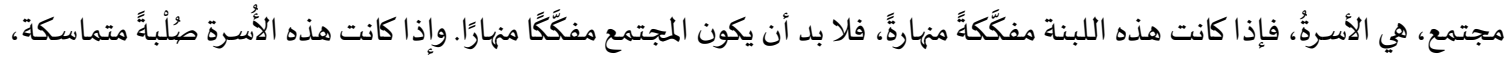

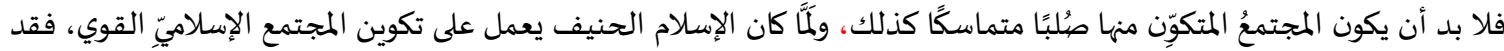

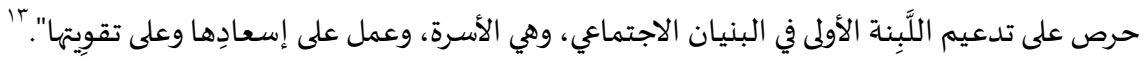

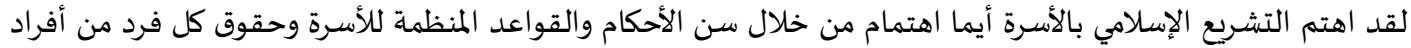

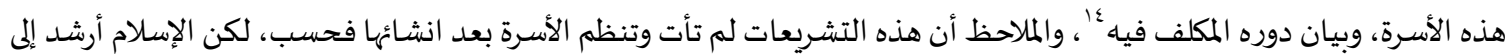

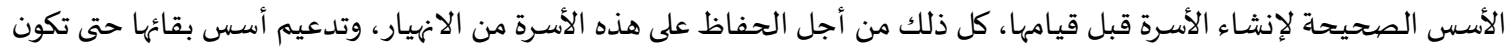

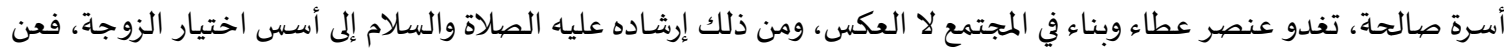

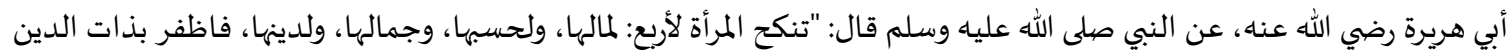

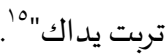

وفي المقابل فقد أرشد الزوجة وأهلها إلى مواصفات من يقبلونه زوجاً، فعن أبي هربرة رضي الله عنه، قال: قال رسول الله صلى

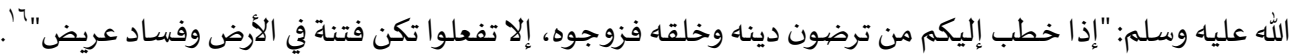

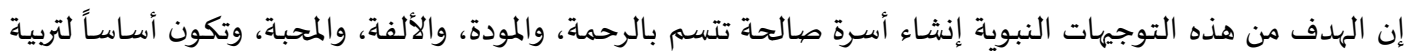

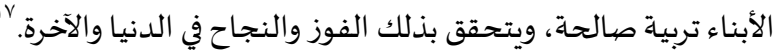

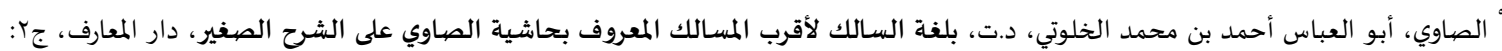

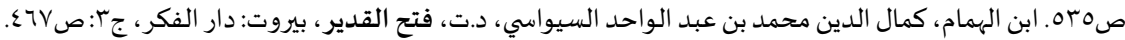

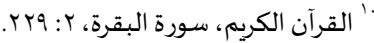

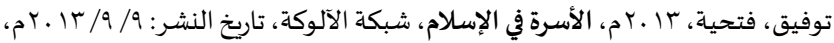
http://www.alukah.net/sharia/0/59694/\#ixzz3zjYL4X7w

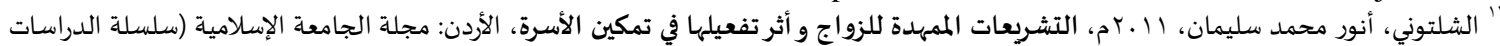

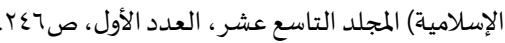

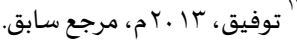



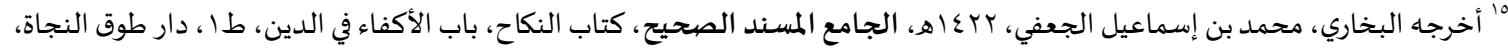

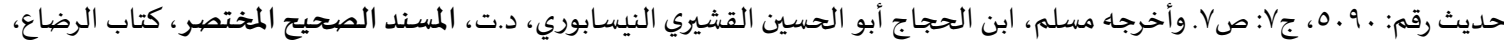

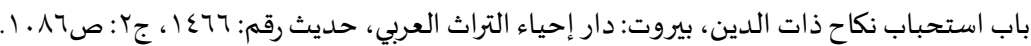

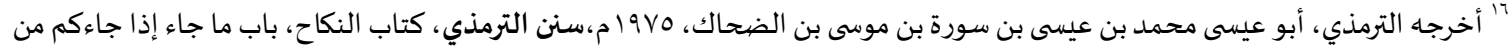

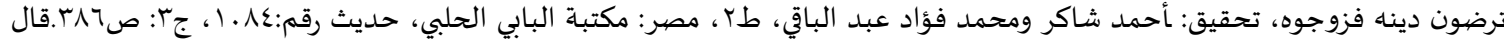
الآلباني: حسديث حسن.

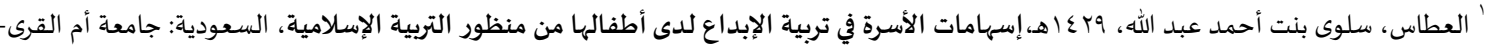


إن الناظر إلى الثروة الفقهية المتعلقة بالأسرة، وما ينبثق عنها من أولاد، وحقوق كل فرد من أفراد هذه الأسرة، يتبين له مدى

اهتمام الإسلام في الأسرة، والسعي إلى جعلها أسرة صالحة متحابة تحقق مراد الله تعالى من إنشائها.

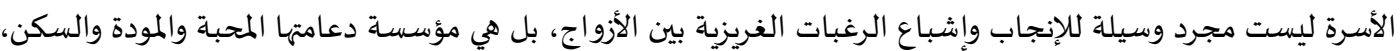

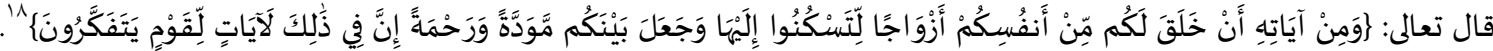

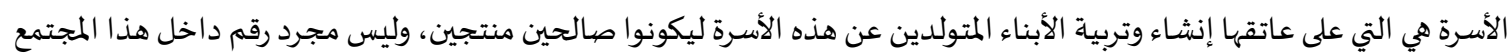

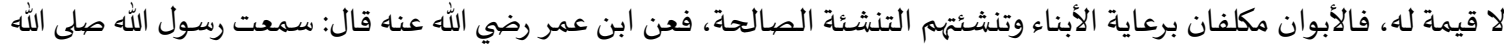

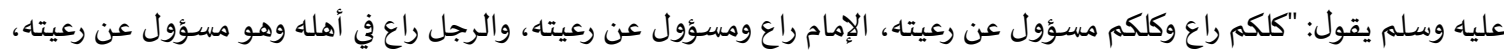

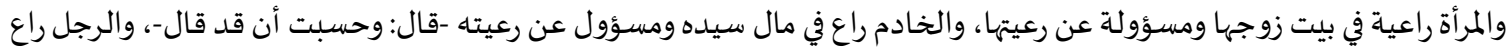

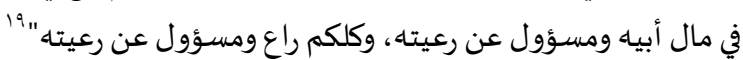

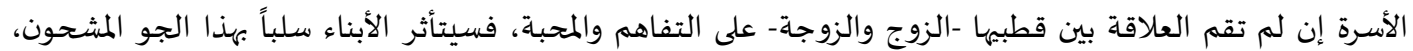

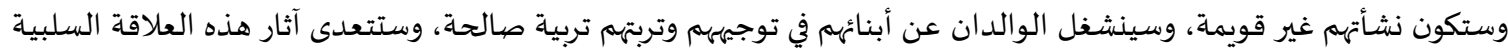

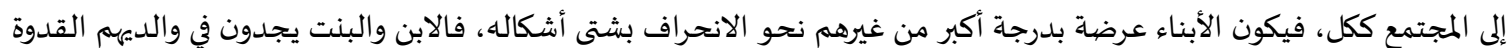

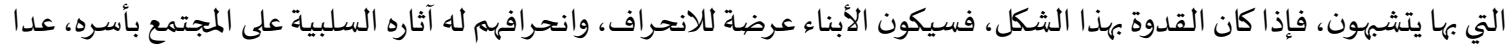

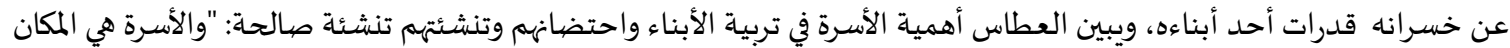

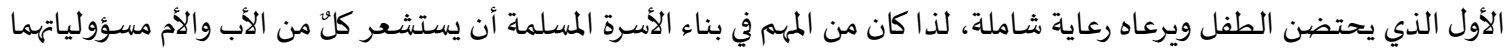

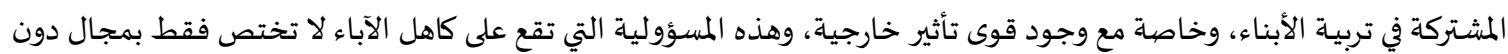

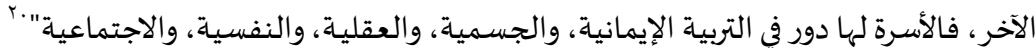

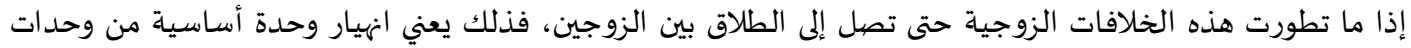

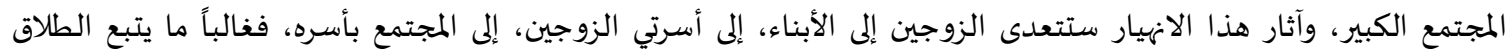

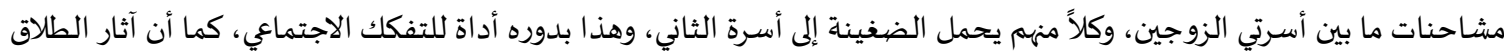

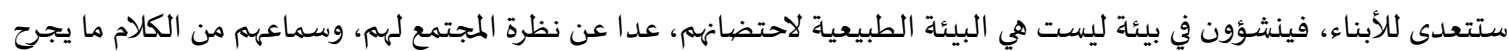

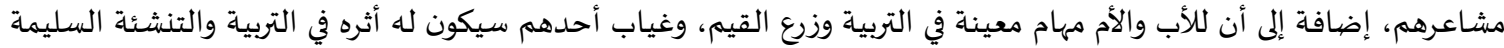

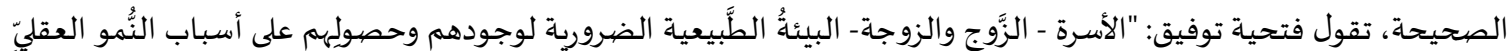

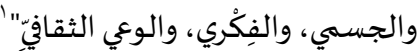

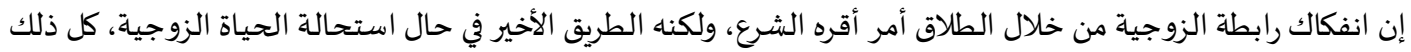

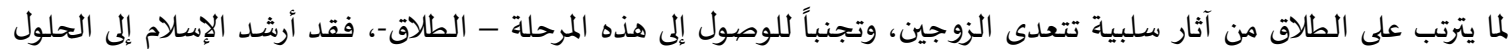

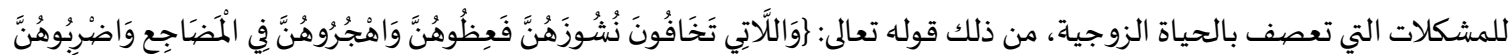

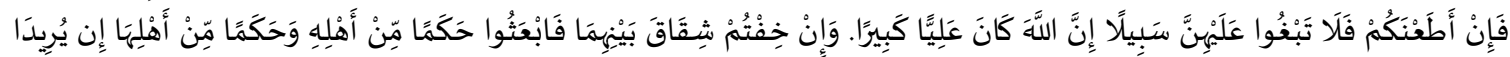

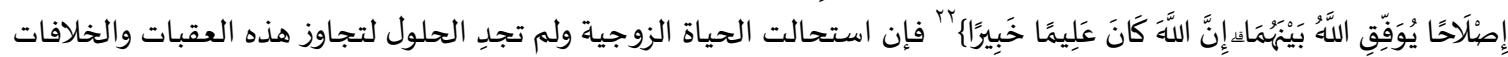

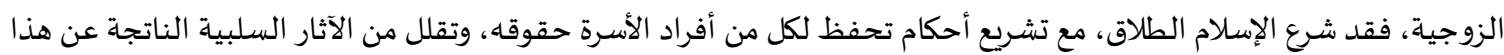

الطلاق.

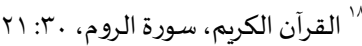

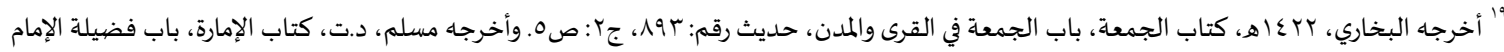

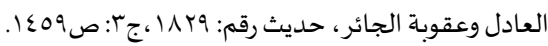

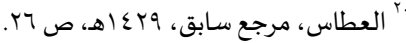

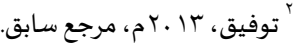

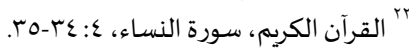
المجلة الدولية للدراسات الإسلامية المتخصصية ـ المجلد ، العددا - 19 ب r 


\section{المبحث الثاني: الطلاق في فلسطين إحصائيات وأسباب \\ المطلب الأول: الطلاق في المجتمع الفلسطيني أرقام وإحصيائيات}

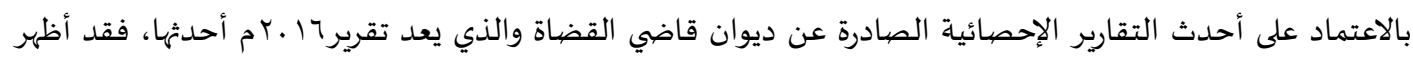
وجود نسب مرتفعة للطلاق مقارنة بحالات الزواج، ففي حين أظهر التقرير السنوي أن عدد حالات الزواج في الضفة الغربية الغربية بلغت

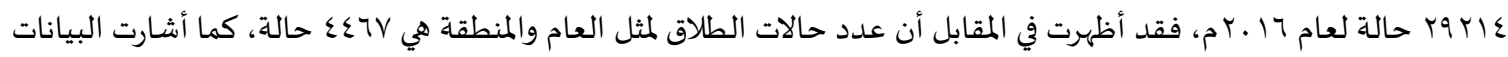
المرصودة أن نسبة حالات الطلاق التي تمت قبل الدخول فاقت نسبة الحالات التي تمت بعد الدخول، فبلغ عدد الحالات التي تم

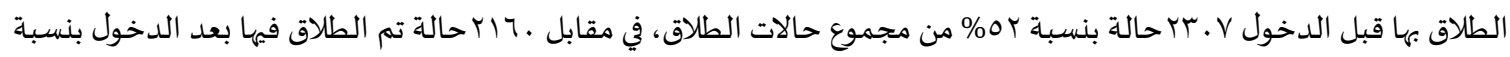

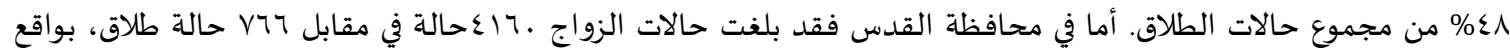

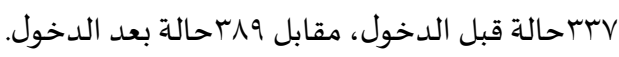

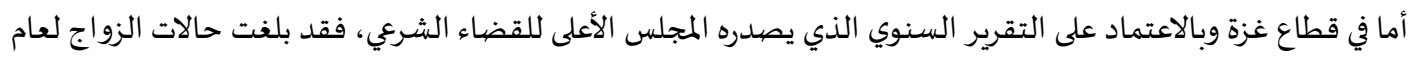

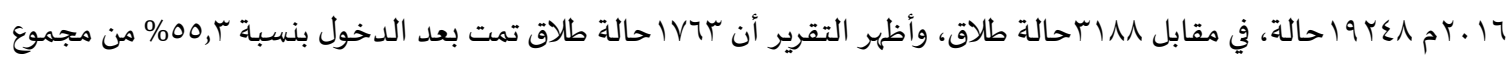
حالات الطلاق، في مقابل

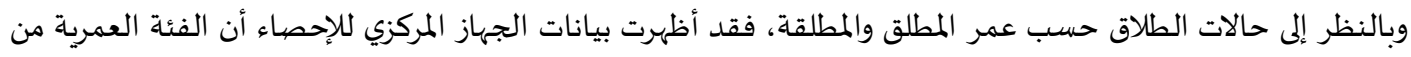

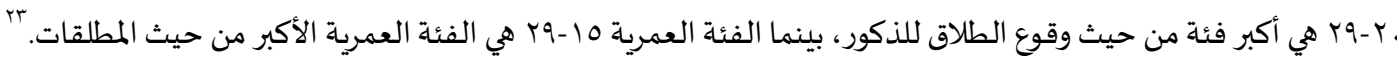

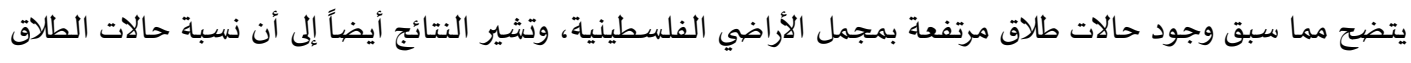
قبل الدخول مرتفعة؛ فهي تقارب نصف حالات الطلاق مجتمعة، وهذا مؤشر خطير، وبالنظر إلى نسب الطلاق خلال الأعوام السابقة

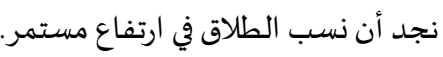
ويتضح من الإحصائيات السـابقة أن معدل الطلاق في فلسطين آخذ بالازدياد مع تقدم الزمن، حيث أشارت الإحصائيات إلى إلى

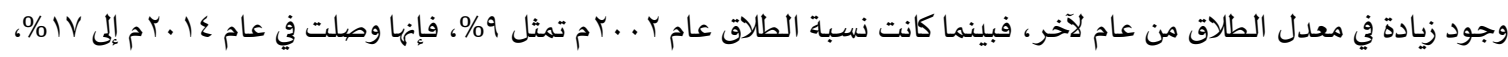

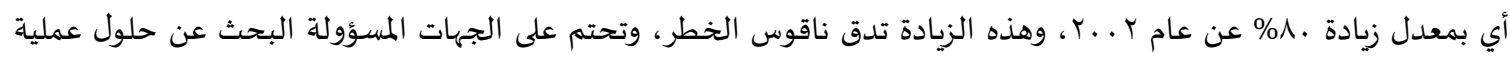

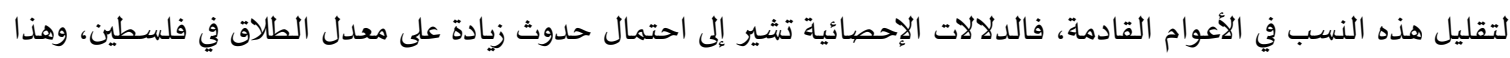

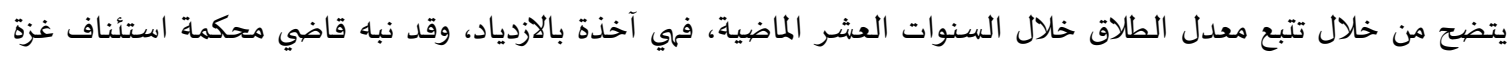

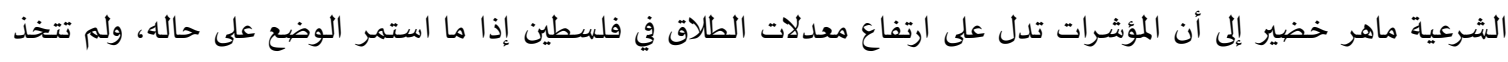

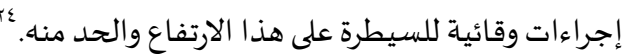

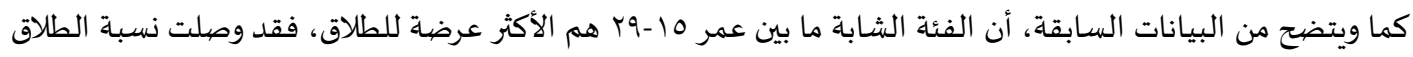

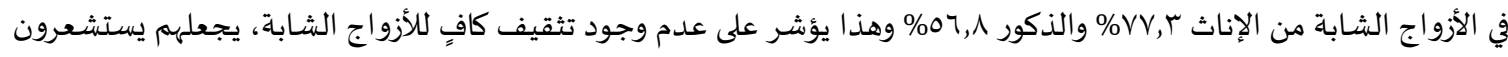

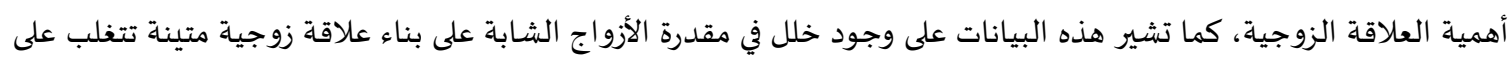

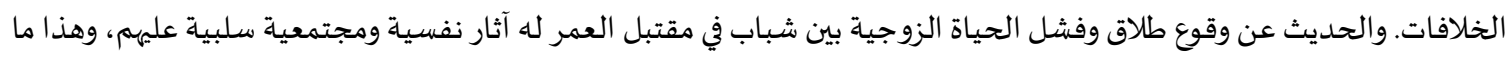

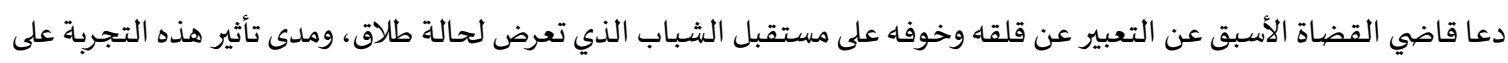

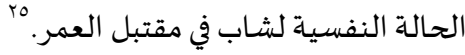
كما ويظهر من الإحصائيات سابقة الذكر، أن ما يقارب نصف حالات الطلاق تقع قبل الدخول، وهذه نسبة مرتفعة وتؤشر

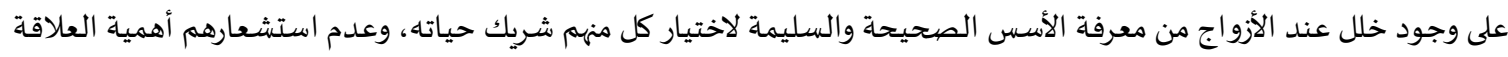
الزوجية، وقد أشار إلى هذا الأمر مفتي محافظة جنين الشيخ محمد أبو الرب، وعد أهم أهم أسباب ارتفاع نسبة الطلاق قبل الدخول

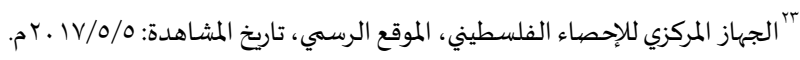
http://www.pcbs.gov.ps/Portals/_Rainbow/Documents/VS-2016-08a.htm

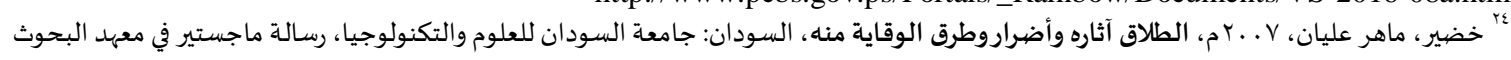

والدراسات الإسلامية.

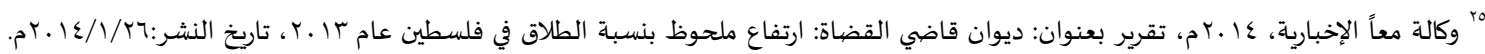
http://www.maannews.net/Content.aspx?id=668240

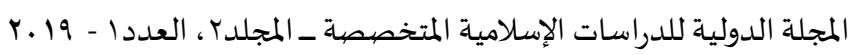


يعود إلى جهل المقبلين على الزواج بأهمية العلاقة الزوجية، واعتقاد البعض أهها مقتصرة على العلاقة الجنسية، دون الإملام بأهمية

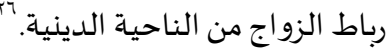

المطلب الثاني: أسباب الطلاق في المجتمع الفلسطيني

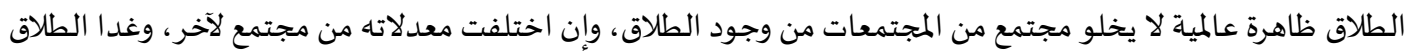

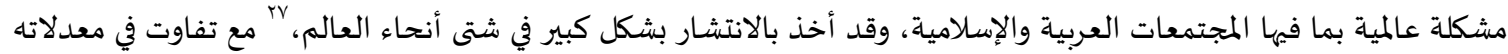

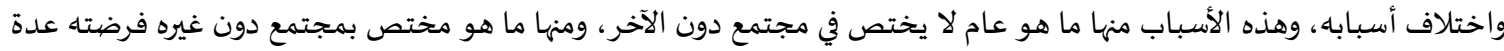

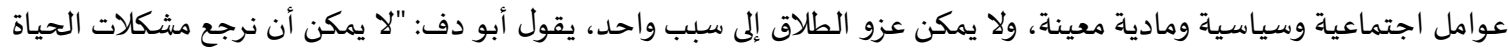

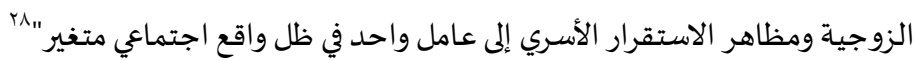

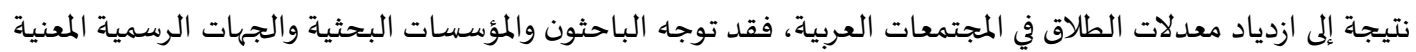

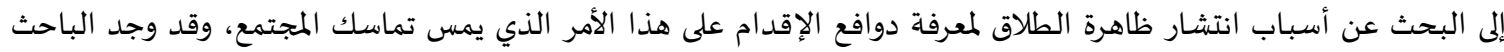

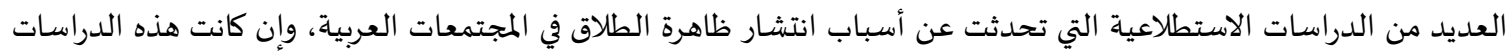

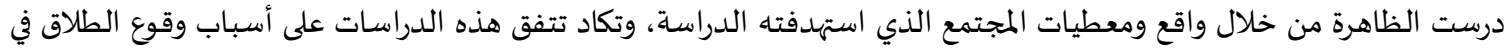

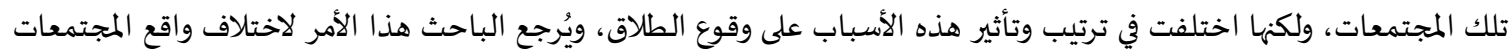

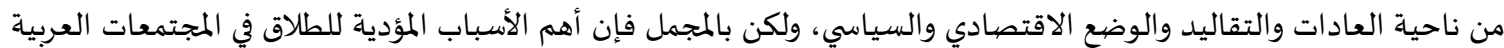

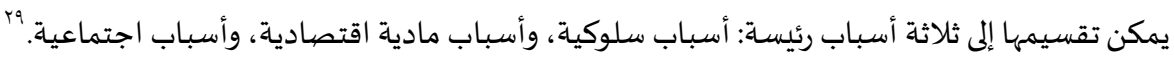

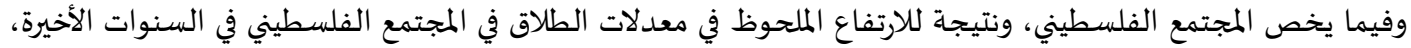
فقد سعت عديد من الدراسات إلى البحث في أسباب الطلاق في المجتمع الفلسطيني، ومن هذه الدراسات: دراسة الغناع الماتيهي والتي نفذاتها

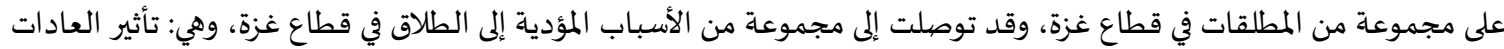

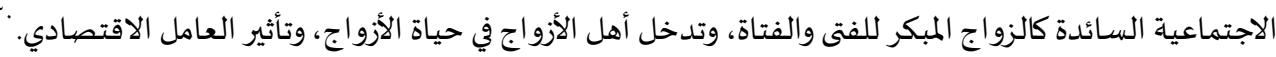

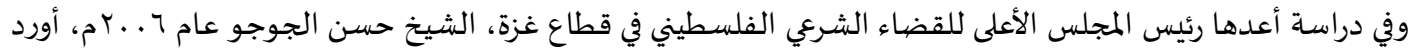

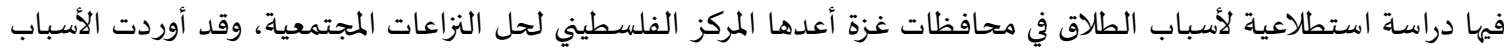

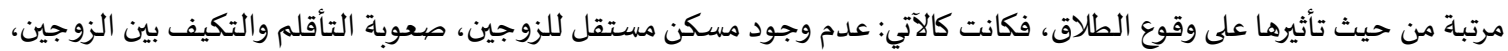

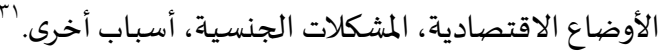

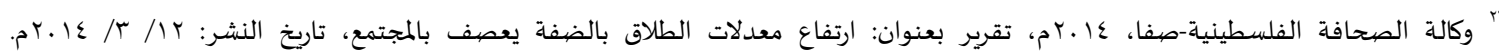
http://cutt.us/8gkUh

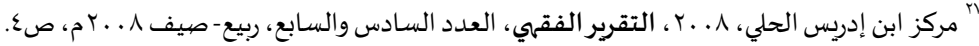

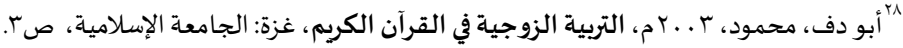

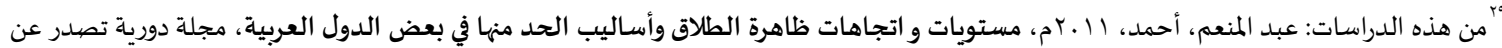

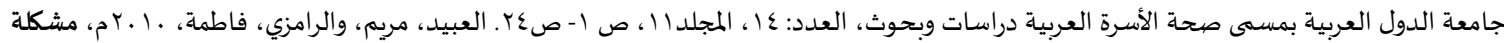

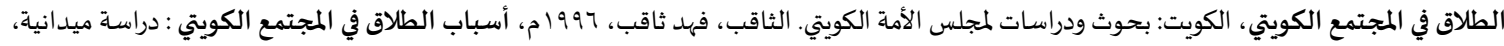

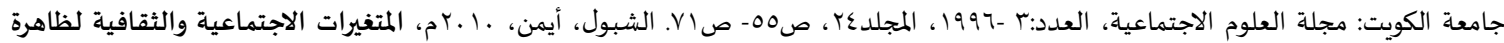

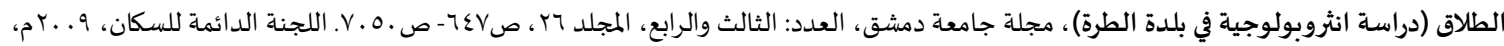

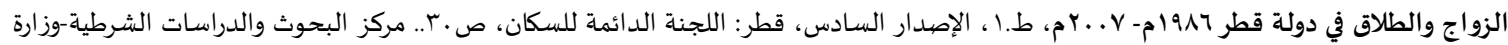

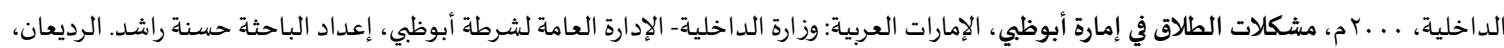

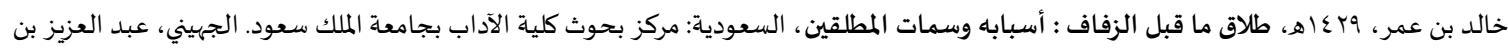

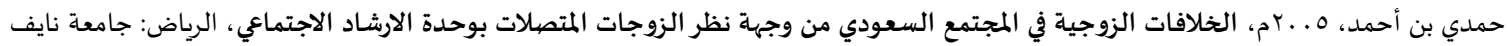

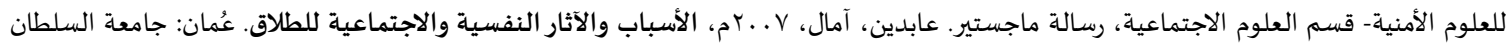

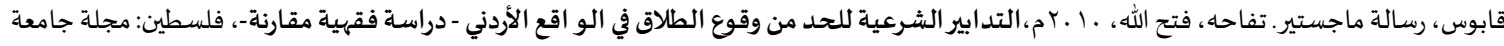

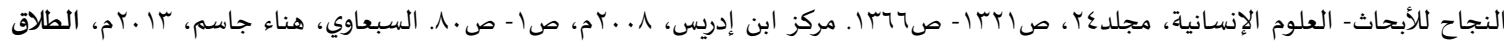

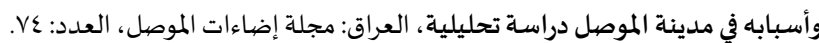

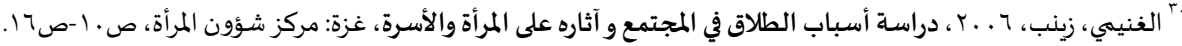

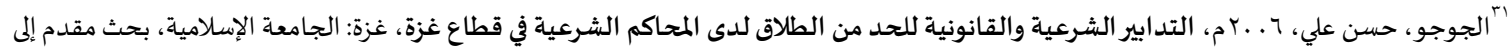

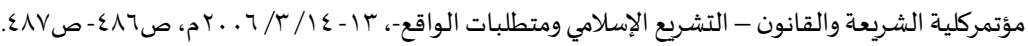
المجلة الدولية للدراسات الإسلامية المتخصصة _ المجلدr، العددا - 19. T 


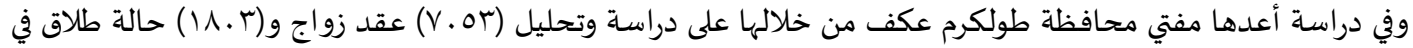

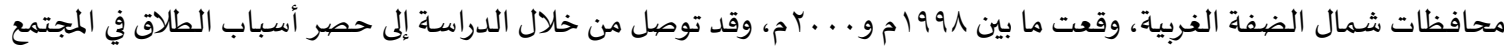

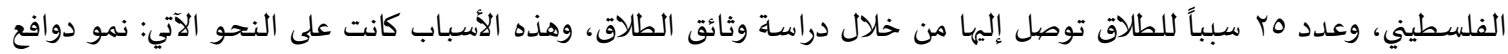

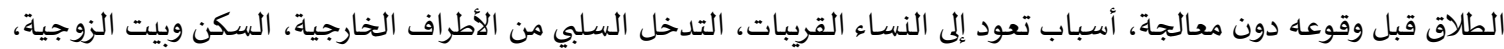

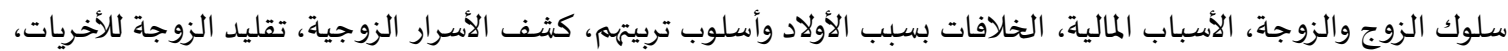

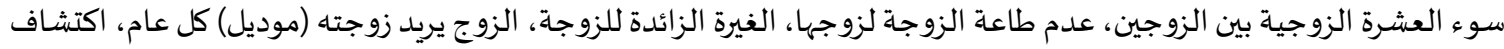

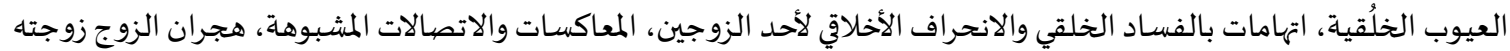

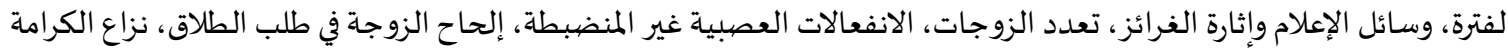

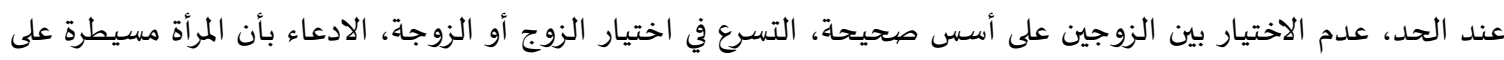

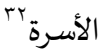

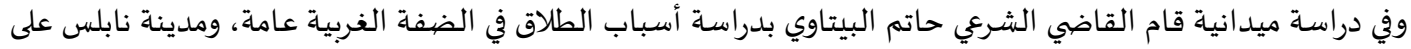

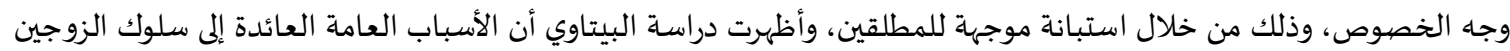

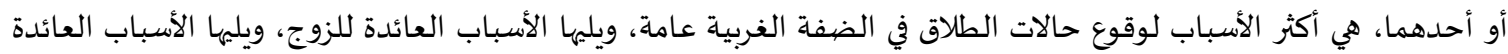

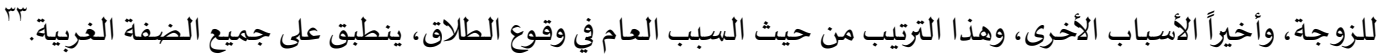

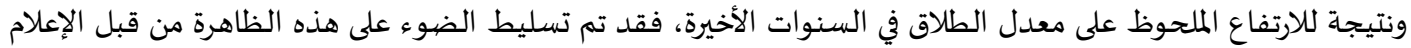

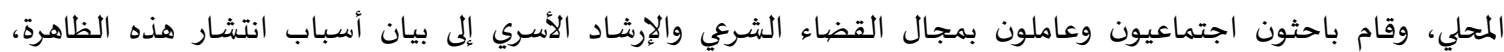

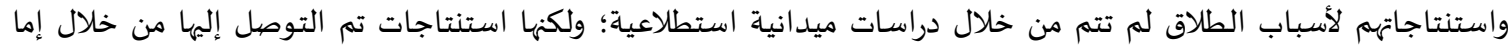

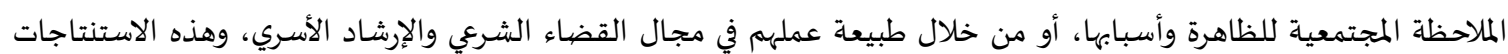

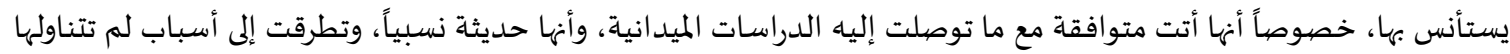

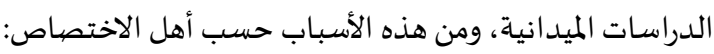
ما ذكره رئيس المجلس الأعلى للقضاء الشرعي في اليوم الدراسي الذي عقدته جمعية فتيات الغد الفلسطينية، وقد عزا

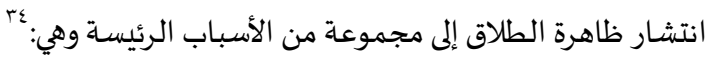

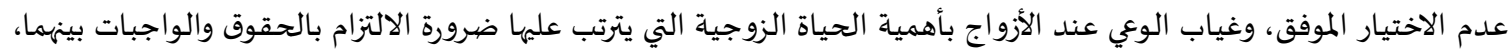

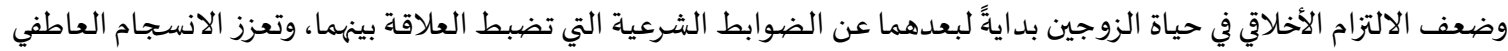

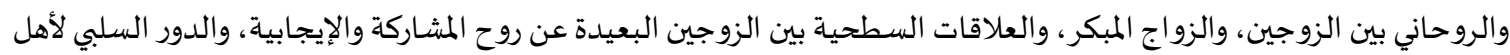

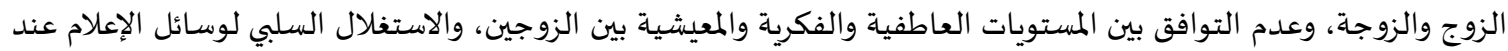

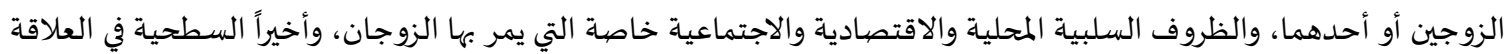

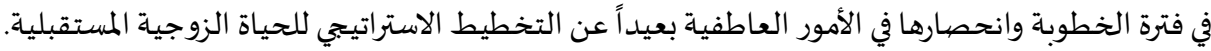

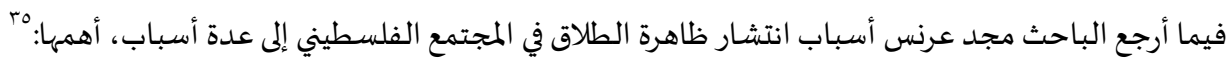

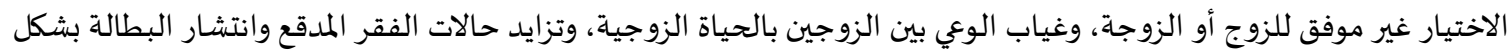

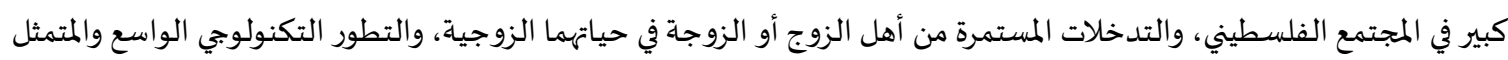

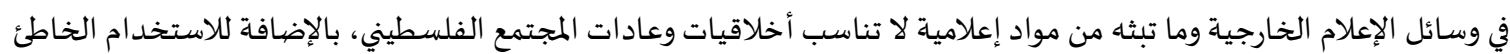
لمواقع التواصل الاجتماعي ودور هذا الاستخدام في خلق النزاعات الزوجية التي تصل إلى الطلاق.

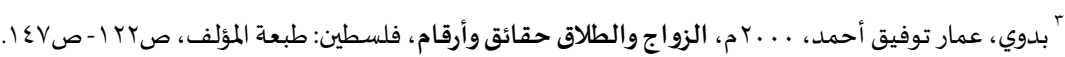

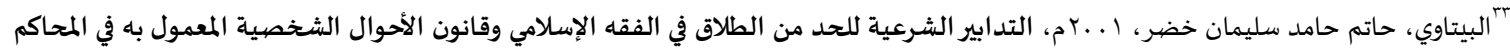

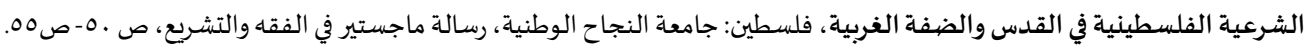

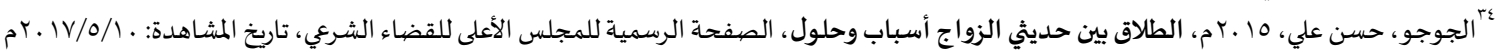
http://www.ljc.gov.ps/index.php?option=com_content\&view=article\&id=747:2015-12-30-11-53-07\&catid=19:201001-18-08-34-22

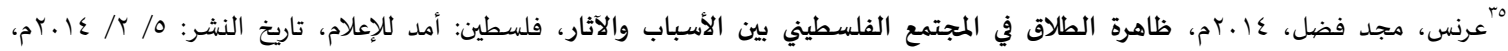
http://www.amad.ps/ar/Details/13926 المجلة الدولية للدراسات الإسلامية المتخصصية _ المجلد ، العددا - 19 ب r 
فيما ذكر الدكتور حمدان الصوفي أستاذ التربية وأصولها في الجامعة الإسلامية أبرز الأسباب المؤثرة في ارتفاع معدل الطلاق

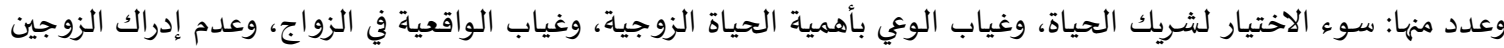

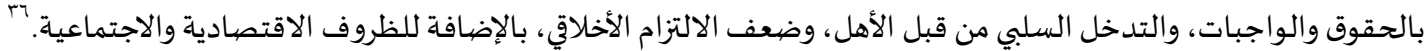

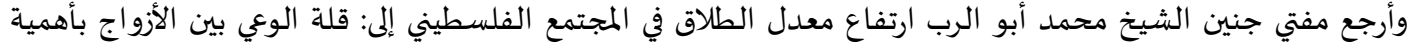

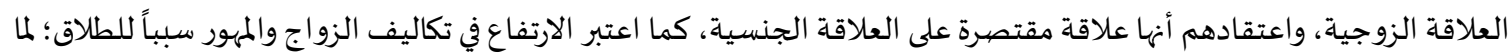

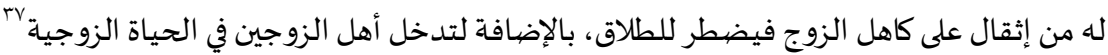

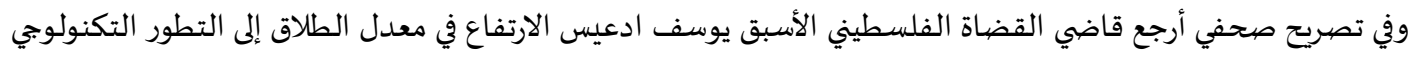

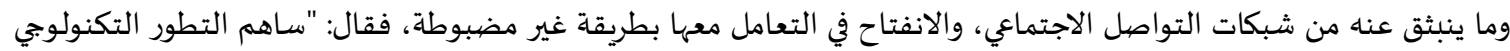

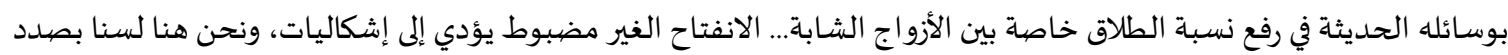

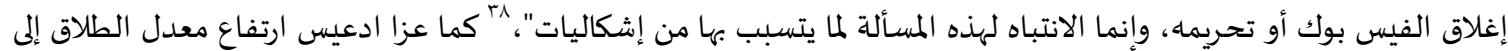

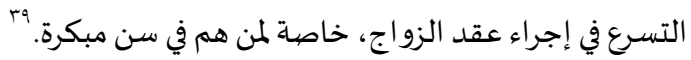
وفي لقاء صحفي آخر بين قاضي القضاة الأسبق يوسف ادعيس أسباب الطلاق، فذكر منها: عدم التفاهم بين الزوجين فئن فئ فئ

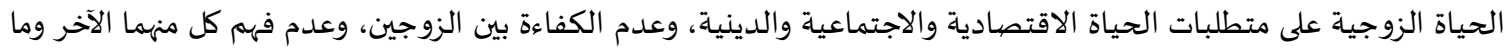

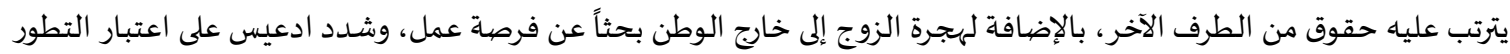

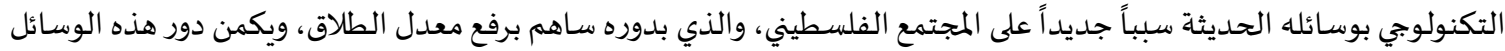

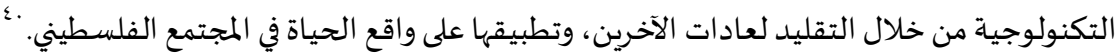

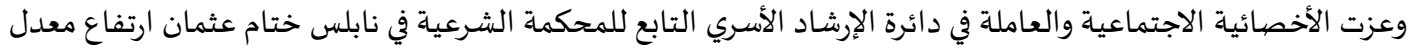

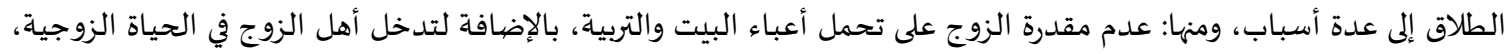

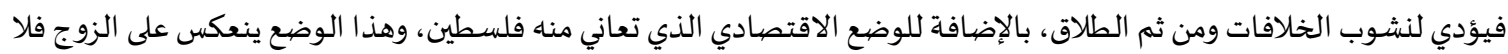

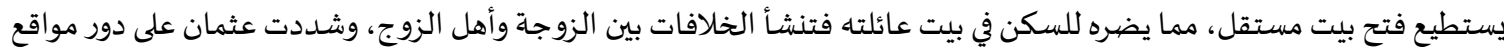

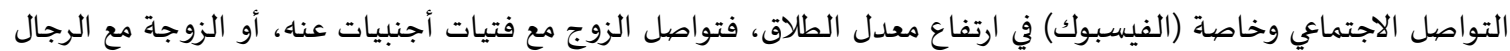

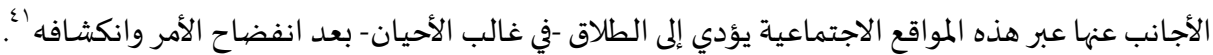

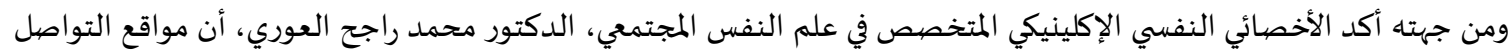

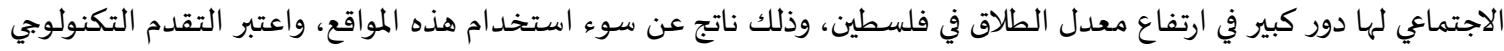

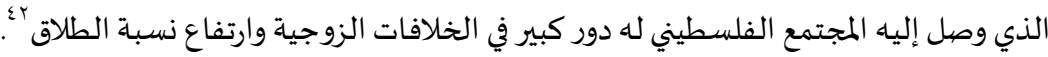
بعد استعراض أسباب الطلاق في المجتمع الفلسطيني من خلال الدراسات الميدانية، ورأي الباحثين الاجتماعيين والقائمين

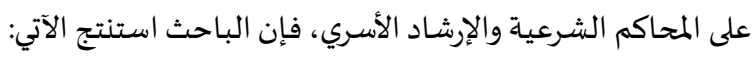
المجتمع الفلسطيني كبقية المجتمعات العربية يشترك معها في معظم أسباب الطلاق.

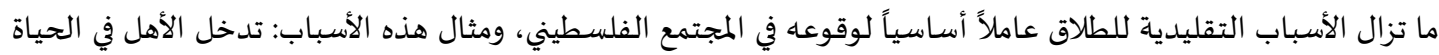
الزوجية، سوء الاختيار، عدم التفاهم. تميز المجتمع الفلسطيني عن غيره من المجتمعات بوجود سبب خاص للطلاق باه دون غيره من المجتمعات، وهو الاحتلال

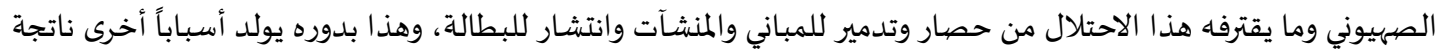

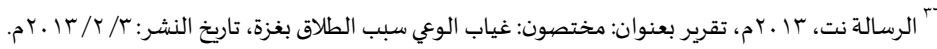
http://alresalah.ps/ar/index.php?act=post\&id=84027

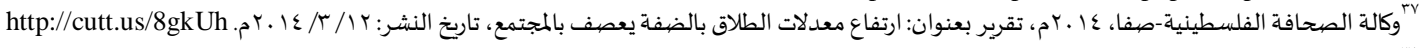

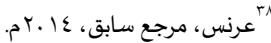

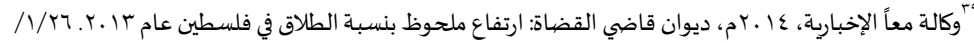

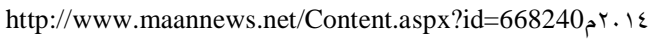

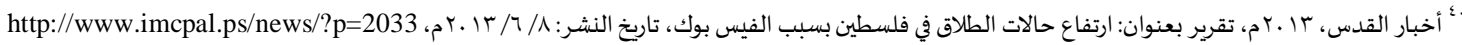
ع ألمرجع السابق.

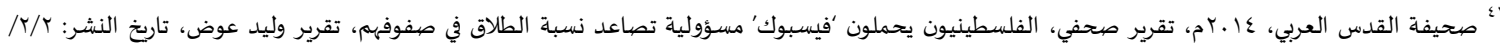

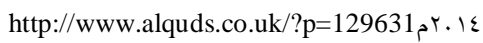


عنه، من خلال عدم مقدرة الشباب على تأمين بيت مستقل عن بيت العائلة، إضافة لما يقوم بـ الاحتلال من اعتقال وسجن

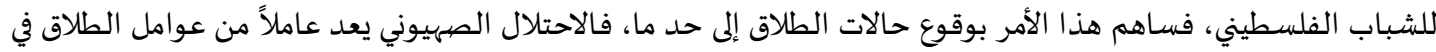
المجتمع الفلسطيني، سواء بطريقة مباشرة أو غير مباشرة.

لفت بعض العاملين في سلك القضاء الشرعي إلى بروز سبب جديد للطلاق لم يكن معهوداً في السنوات الماضية، وهو مواقع

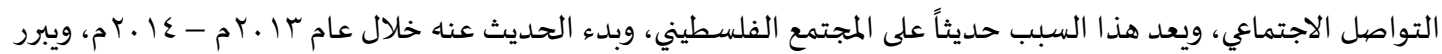
هذا الأمر أن التطور التكنولوجي في فلسطين شهد نقلة وقفزة كبيرة خلال السنوات الماضية، ويظهر ذلك من خلال الإحصاءات،

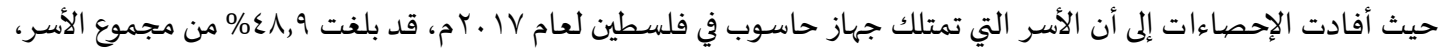

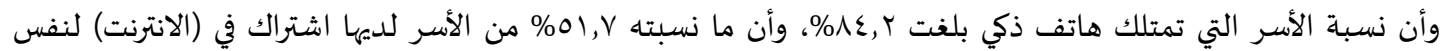

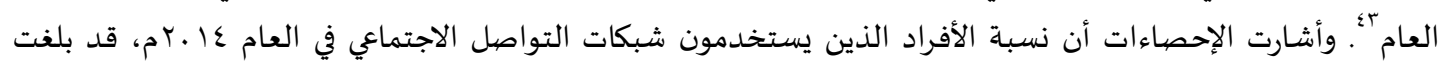

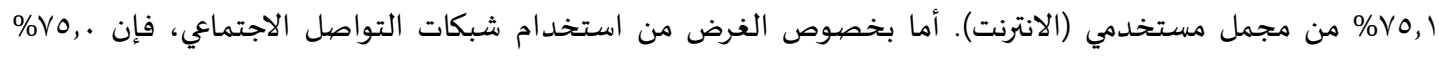

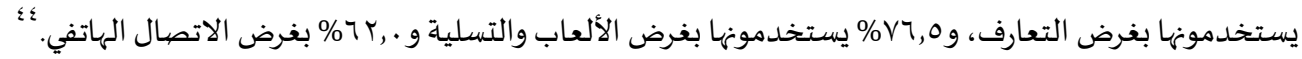

\section{المبحث الثالث: الدورات التأهيلية للمقبلين على الزواج الماهية والمشروعية}

المطلب الأول: الماهية والأهمية للدورات التأهيلية للمقبلين على الزواج

كثر الحديث في الآونة الأخيرة عن ضرورة تأهيل الشباب المقبل على الزواج، والعمل على توعيته بأسس الحياة الزوجية وآلية

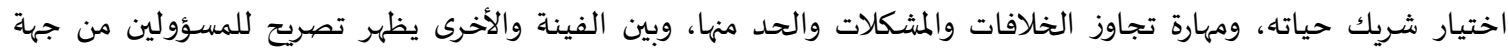

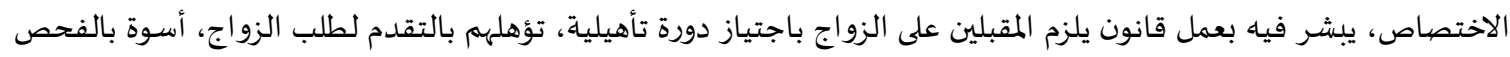
الطبي، وغالباً ما تأتي هذه التصريحات بعد إصدار الإحصائيات المخبرة بارتفاع نسبة الطلاق عن العام السابق، ومن الأمثلة على ذلك:

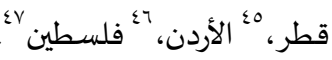

وترجع فكرة إرشاد المقبلين على الزواج إلى ثلاثينيات القرن العشرين، في الولايات المتحدة الأمريكية، وتطورت الفكرة

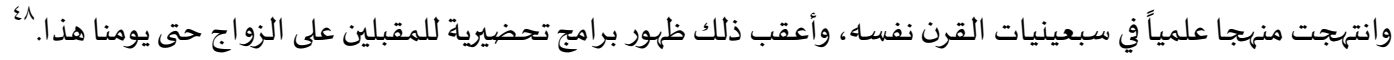

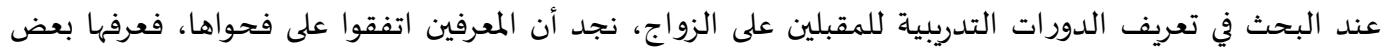

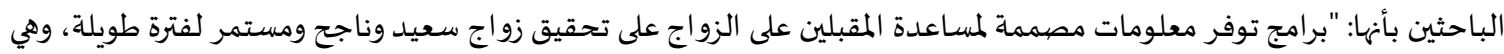

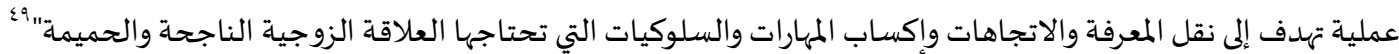

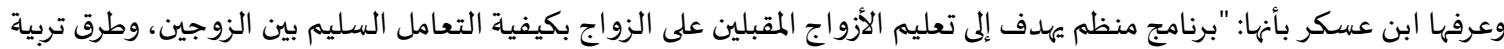

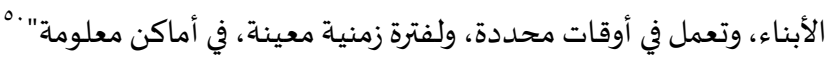

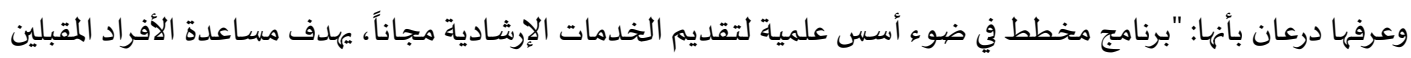

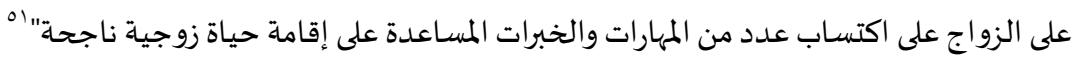

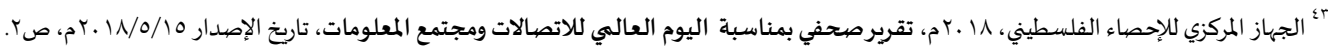

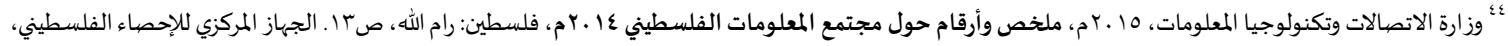

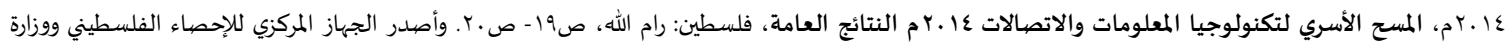

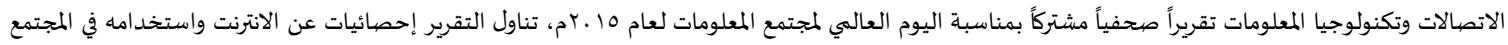
الفلسطيني. sharq.com/news/details/271281

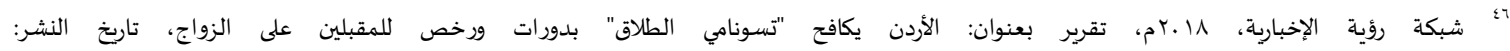
://www.roayahnews.com/new r. 1N/r/rq

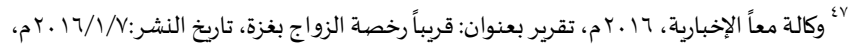
https://maannews.net/Content.aspx?id=819641

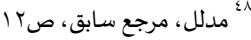

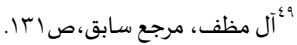

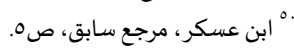

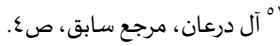




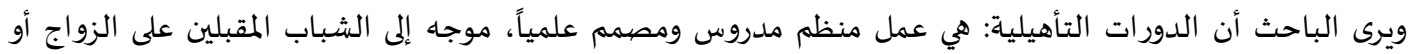
المتزوجين فعلياً، وهيدف إلى إكسابهم مهارات تساعدهم على بناء أسرة سعيدة، وتساعدهم على تجاوز الخلافات الزوجية، وتعريفهم بأسس تربية الأبناء السليمة.

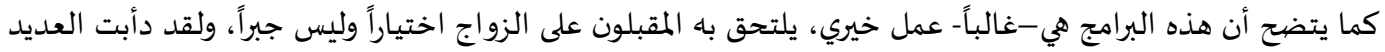

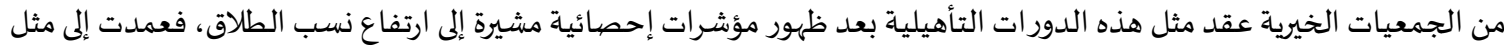

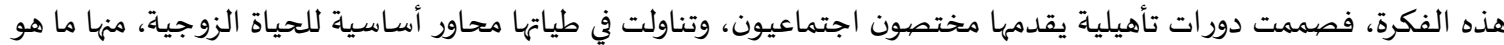

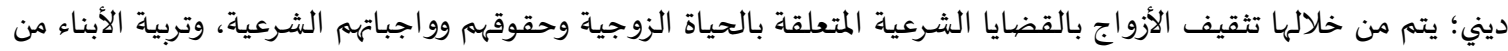

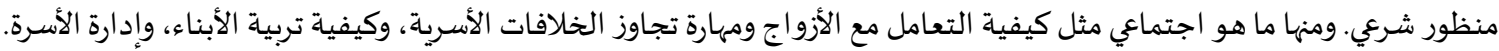
ومنها ما هو نفسي، وهو المتعلق بالقضايا النفسية كالخوف والقلق من الزواج، والتربية الجنسية، والآثار النفسية للمشكائلات الأسرية.

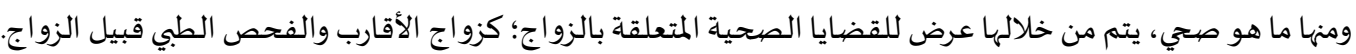

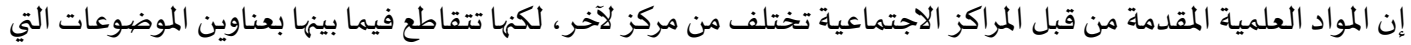

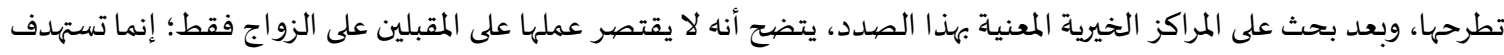

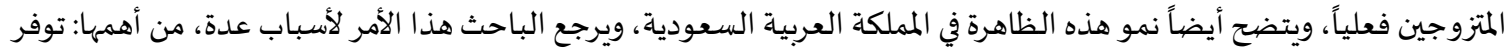

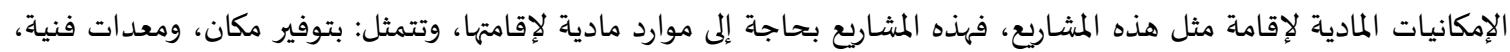

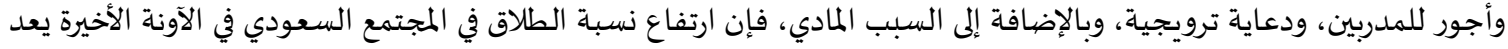

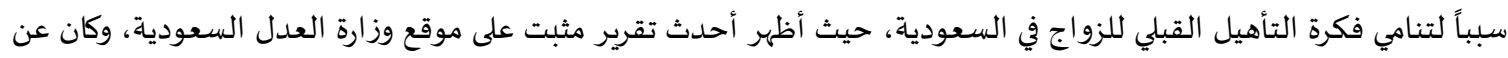



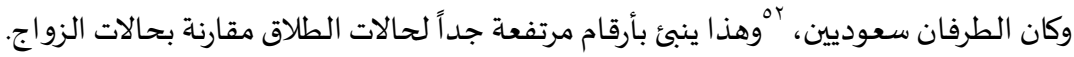

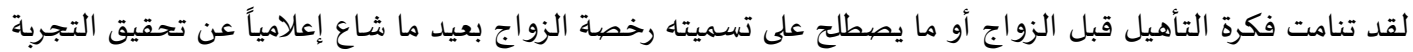

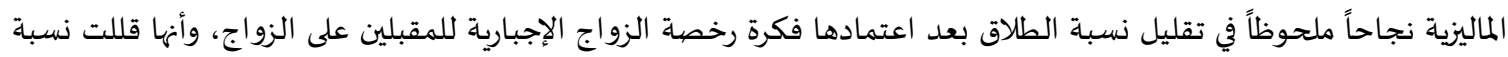

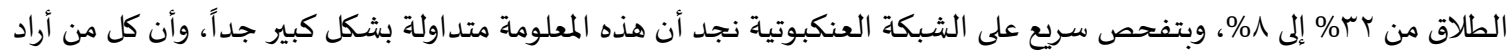

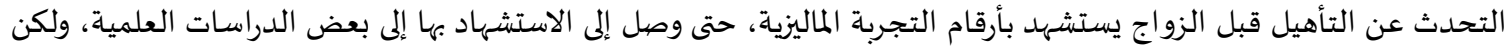

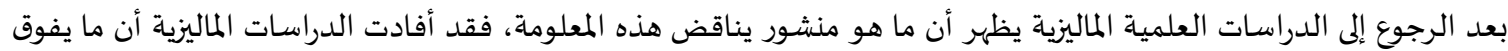

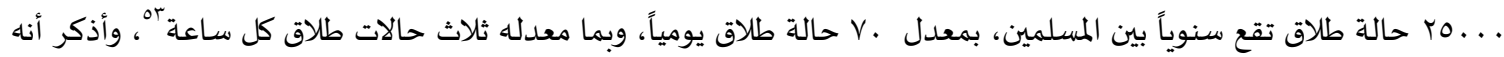

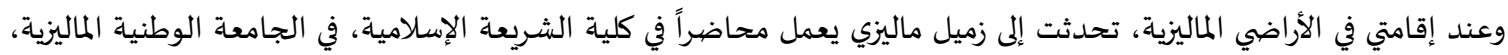

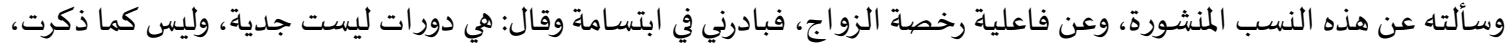
ونسب الطلاق عندنا مرتفعة.

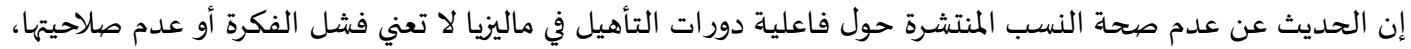

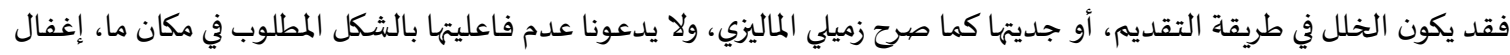

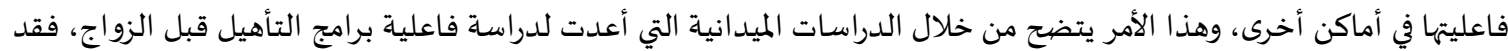

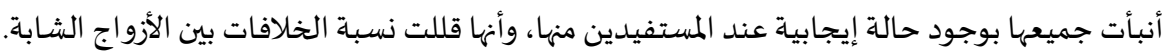

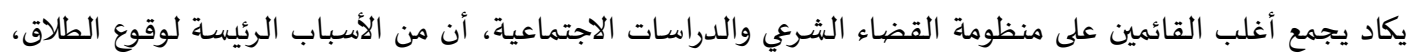

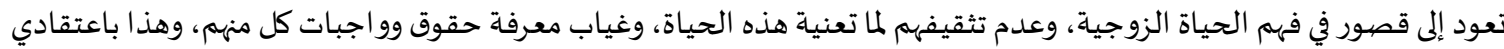

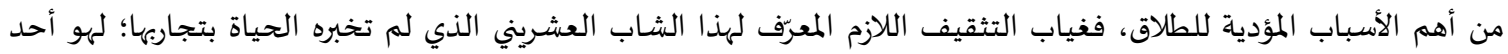
الأسباب الرئيسة لهذا الارتفاع في حالات الطلاق.

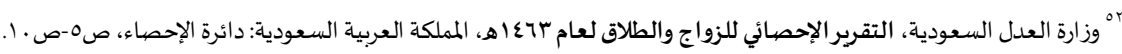
${ }^{53}$ Muhammad FakhrulAzimHasbullah, and Noor 'Aina Abdul Razak, 2017, Divorce Cases Among Muslims: Demographic Study of Daerah Barat , International Academic Research Journal of Social Science 3(1) 2017 Page 154-158. Noor AziahMohdAwal, (2013), Tigakespenceraianpasangan Muslim setiap jam. Malaysiakini. https://m.malaysiakini.com/news/237984 
غالباً ما يسهى الزواج، بالحياة الزوجية، وفعلاً هي حياة، حياة بكل تفاصيلها، لها قوانيها المسيرة لها التي يجب إدراكها

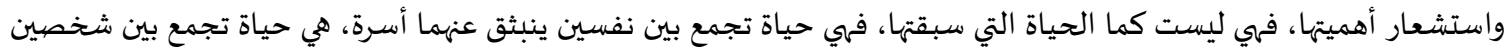

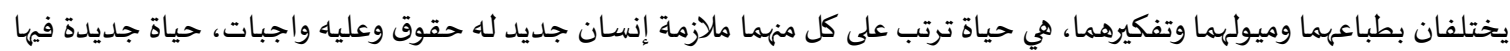

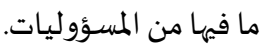

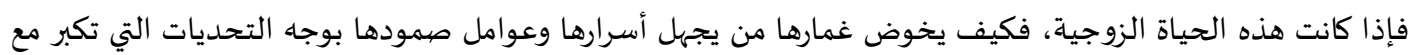

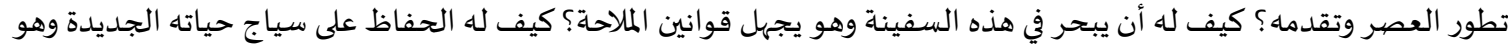

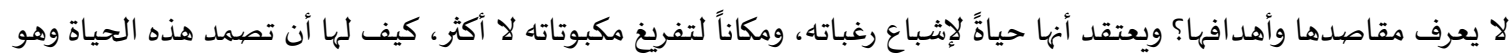

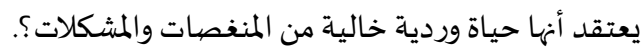

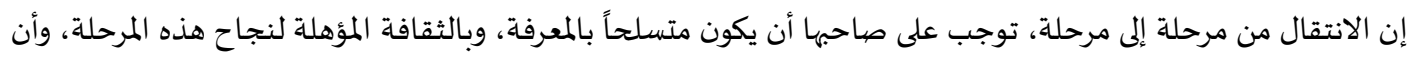

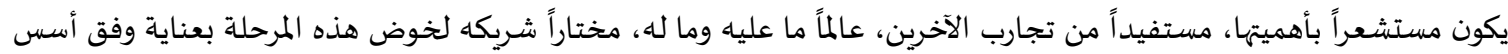

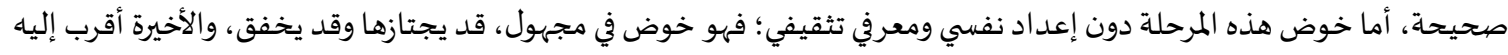

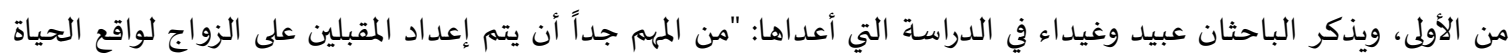

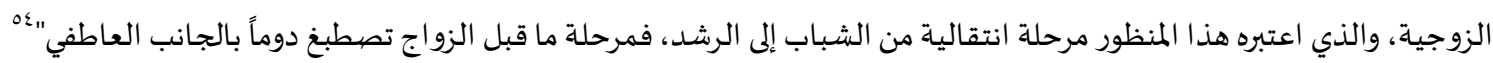

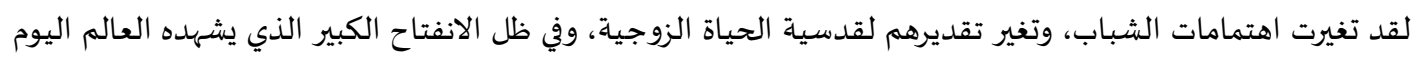

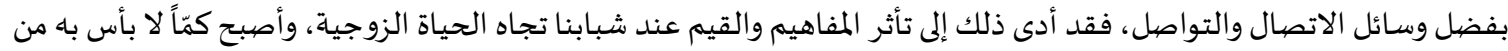

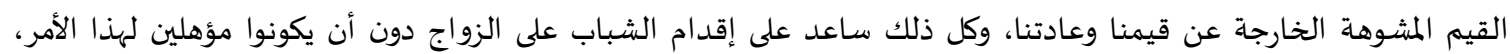

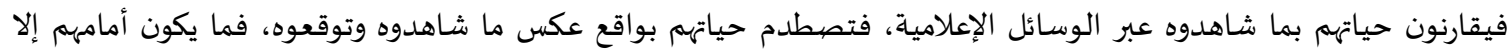

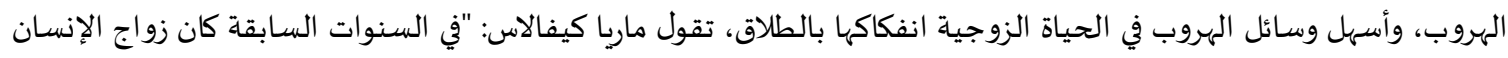

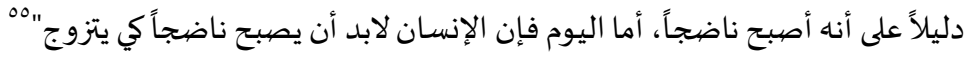

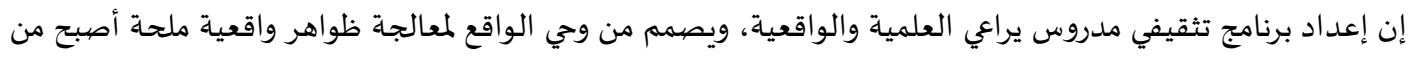

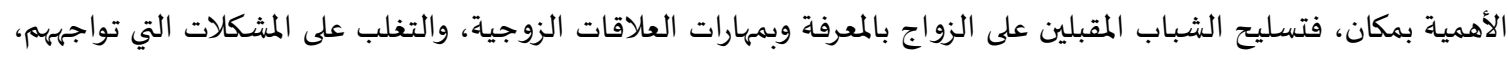

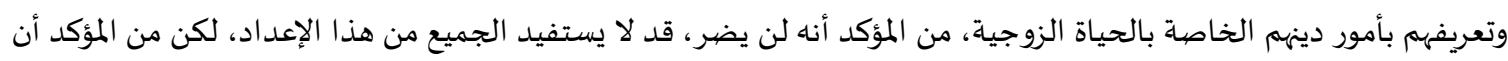

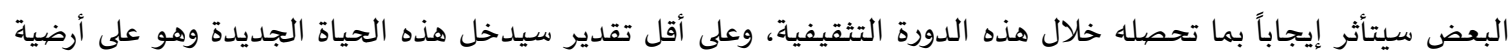

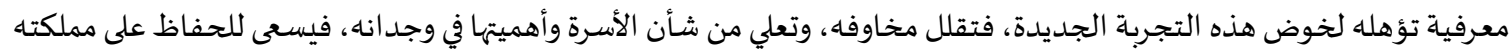
قدر الإمكان من الانهيار. من المؤكد أن التثقيف القبلي لن يمنع جميع حالات الطلاق، لكنهاه سيقلل منها، خصوصاً عندما ننظر إلى أسباب الطلاق في

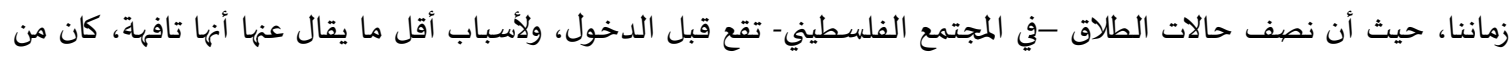

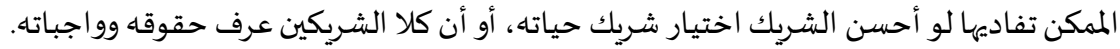

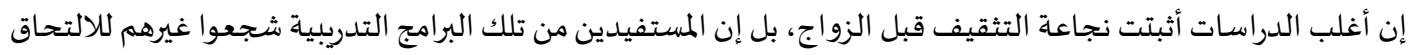

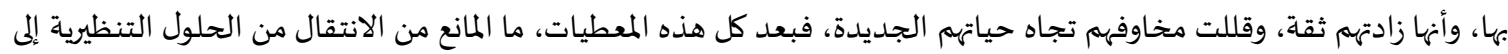

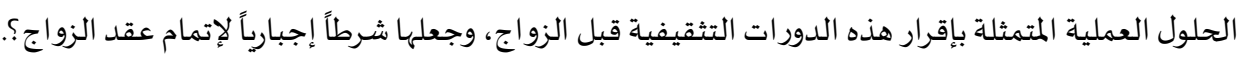

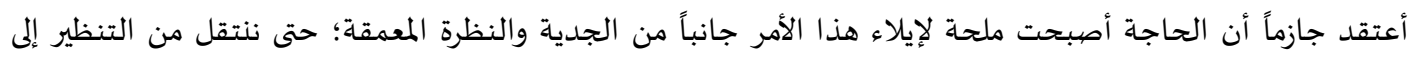

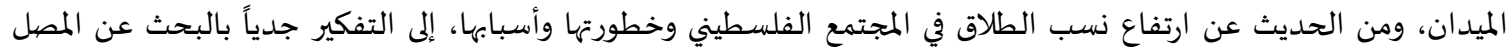

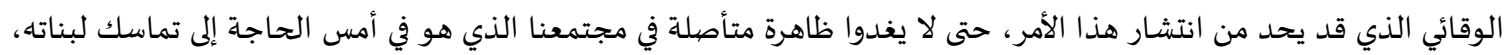

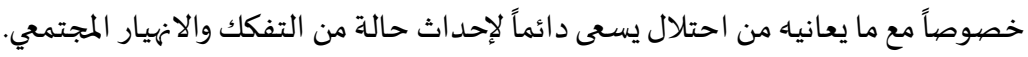

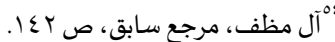
${ }^{55}$ Maria Kefalas, Marriage is more than being together: The meaning of Marriage among young adults in the United

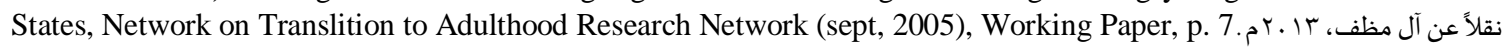
ص 
المطلب الثاني: سلبيات ومعيقات متوقعة لاستحداث دورات تأهيلية للمقبلين على الزواج

لا يمكن الحديث عن استحداث دورة تأهيلية إجبارية لجميع المقبلين على الزواج، وجعلها شرطاً لإتمام عقد الزواج، دون أن يرافقها سلبيات أو معيقات، فمع كل ما تم طرحه من إيجابيات أثبتها الدراسات المعنية، إلا أنه من المؤكد مرافقة هذا الأمر سلبيات ومعيقات متوقعة، ويمكن إجمال أهم السلبيات والمعيقات حسب رؤية الباحث بما يأتي: ا. إقناع المقبلين على الزواج بضرورة اجتياز الدورة التأهيلية لإتمام عقد الزواج، فإقناع المستهدفين بجدوى هذا القانون ليس بالأمر السهل، وقد يتم الاعتراض عليه من قبل المستهدفين من منطلقات عدة: • ظناً منهم مسـاه لكرامتهم، واتهاماً لههم في نضوجهم، فيمنعهم هذا الشعور من الالتحاق بمثل هذه الدورات. • خشية اجتياز الدورة التأهيلية بنجاح، وأن هذا الأمر سيحول بينهم وبين الزواج. • الأسباب المادية؛؛ فحضور مثل هذه الدورات التأهيلية ستكون على حساب عمله، فيفقد شيئًاً من دخله، نتيجة إجباره على اجتياز هذه الدورة. • كونه متعلماً مثقفاً، يملك أدوات وفنيات الحوار وحل المشكلات، فيعتقد أن لا جدوى مرجوة من مثل هذه الدورات التأهيلية. • اعتبار الفكرة برمتها دخيلة على المجتمعات الإسلامية، وهي محاولة تغريبية جديدة، وقد نقل عن وزيري الأوقاف الأردنيين السابقين: عبد السلام العبادي، وعبد الرحيم العكور رفضهما لهذه الفكرة، كونها دخيلة على المجتمع الأردني، وأهها دعوة تغربيية

إن جلَّ هذه المنطلقات مبررة، وهي منطلقة من عدم معرفة حقيقة هذه الدورات التدربية،، وإذا ما قدر وضع قانون ينظم هذا الأمر، فيجب مراعاة هذه التخوفات وإزالها، فعند تشريع قانون ينظم هذه الدورة التأهيلية يشترط فيه المرونة والتدرج ومراعاة أحوال الناس، ومن ذلك على سبيل المثال أن يكون اجتيازها اختيارياً وليس إجبارياً لفترة من الزمن، بل ومن الممكن أن يمنح المستفيد مقابلاً مادياً رمزياً، ومن المهم عقد شراكات مع مؤسسات المجتمع المدني والحكومي، فيتم استهداف طلبة الجامعات بدورة إجبارية للتخرج، وهذه الأمور متروكة للقانون ينظمها بما يتناسب مع ظروف المجتمع وشرائحه المختلفة، وعليه عند وضيع هذا القانون المنظم يجب إشراك جميع الجهات ذات العلاقة والاختصاص. r. إن سن مثل هذا القانون له تبعات مادية، فهو بحاجة إلى كادر مؤهل لإعطاء هذه الدورات التأهيلية، إضافة إلى توفير مكان مناسب لتقديم هذه الدورات، وإعدادها إعداداً جيداً متكاملاً، حتى تكون صالحة لعقد وتقديم هذه الدورات التأهيلية، وهذا بدوره يعني رواتب ونفقات تقع على كاهل الدولة.

إن النفقات أمر لا مفر منه لعقد هذه الدورات، ولكن إذا ما علم أن هذه النفقات سيكون لها الأثر في بناء الإنسان،

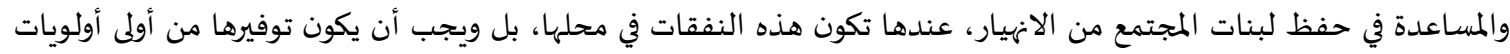

الجهات المختصاة، فالإنسان والأسرة هما الثروة الحقيقية لأي بلد، والاستثمار في الإنسان لا يقل أهمية عن الاستثمار في البنيان.

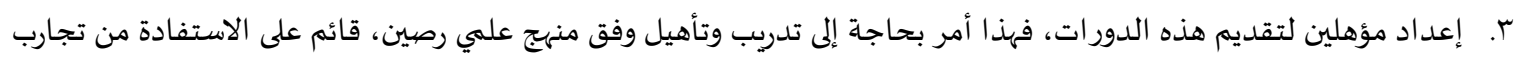
الدول والمراكز التي لها باع في هذا الأمر، إضافة إلى إشراك أصحاب التخصصات العلمية التي لها علاقة بهذا الجانب، فهذا كله

يصب في خانة إعداد مؤهلين لتقديم هذه الدورات حتى تؤتي أكلها.

المطلب الثالث: مشروعية اشتراط الدورات التأهيلية للمقبلين على الزواج

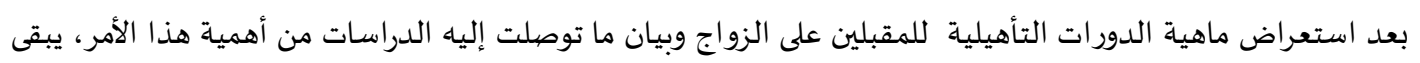
السؤال الآتي: هل يجيز الشرع استحداث شرطاً جديداً على شروط النكاح لم ينص عليه القرآن الكريم والسنة النبوية؟ 
إن الهروب من مثل هذا الاستفسار يكون بجعلها اختيارية لا إجبارية، فنكون بذلك في مأمن من إحداث شيء في شرع الله، الهاء

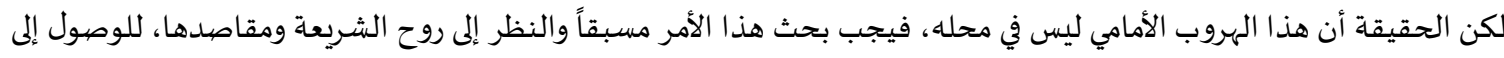
حكم تطمئن إليه النفوس.

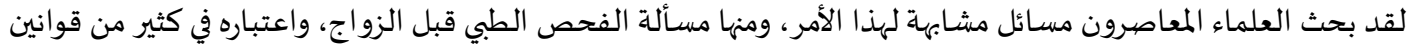

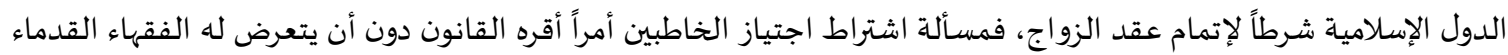

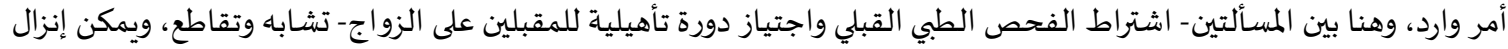
مسألة التأهيل القبلي منزلة الفحص الطبي القبلي. قبل الخوض في مسألة الدورة التأهيلية واشتراطها لإتمام عقد الزواج، من الواجب استحضار مسألة الفحص الطبي والحديث عنها باقتضاب؛ لأهمية هذا بالنسبة لموضوع الدراسة. يعرف الفحص الطبي بأنه (فحص المقبلين على الزواج قبل عقد القران في مراكز صحية محددة لهذه الغاية، للكشف عن الفئ احتمالية

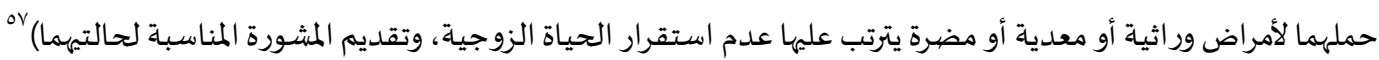
وتعددت آراء المعاصرين إلى رأيين:

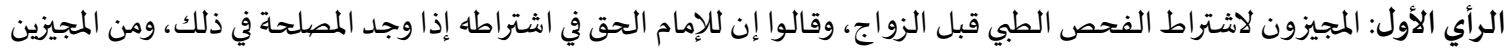

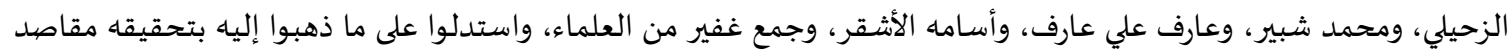

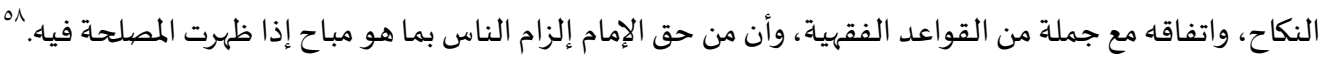

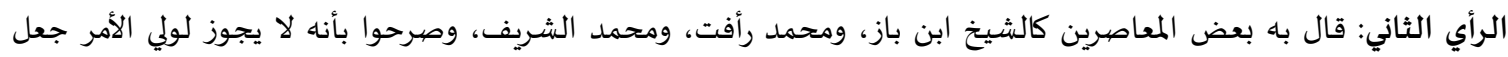

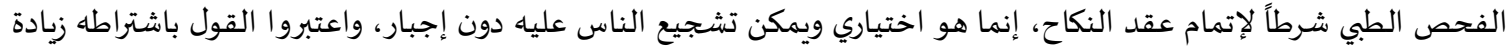

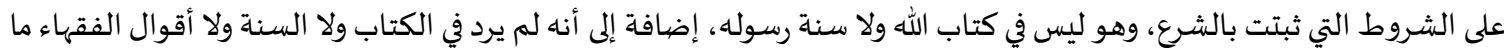

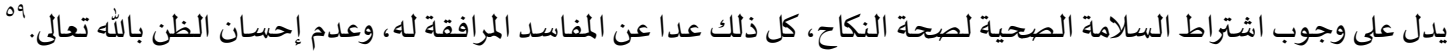

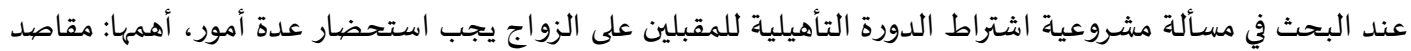

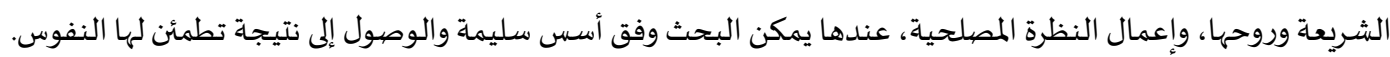

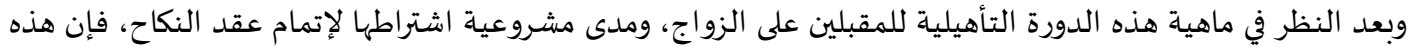

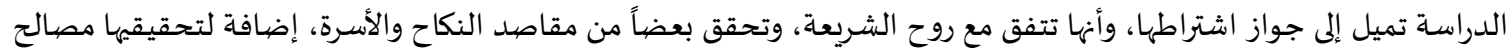
معتبرة تتفق مع الشربعة الإسلامية، ويمكن بيان مستند هذا القاريان القول من خلال الآتي:

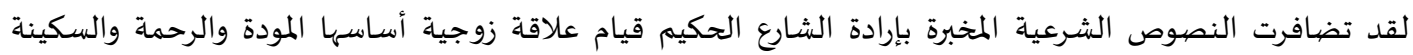

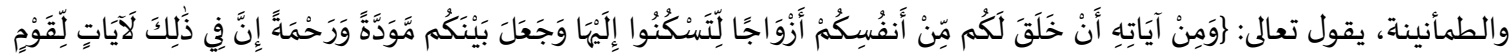

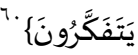

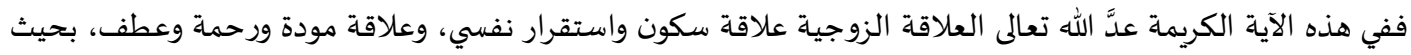

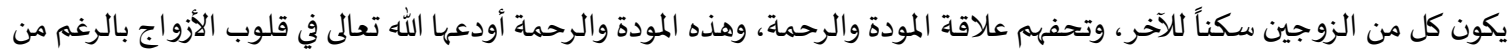

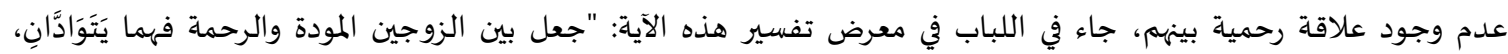

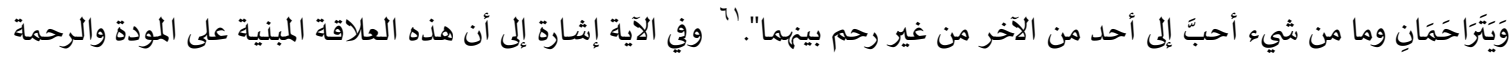

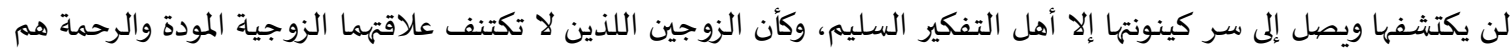

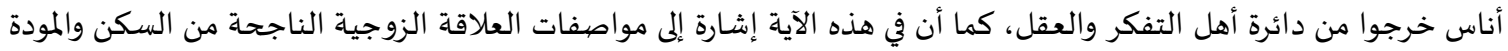

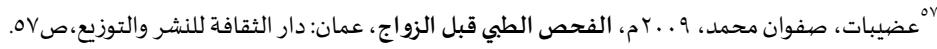

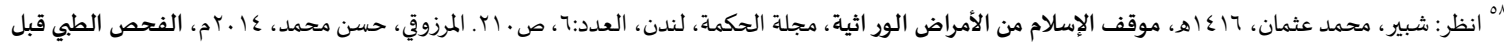

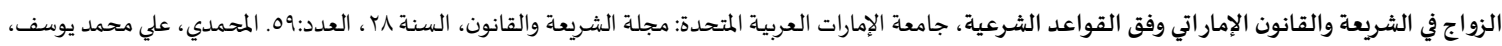

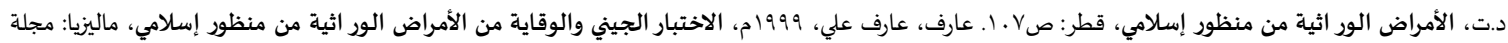

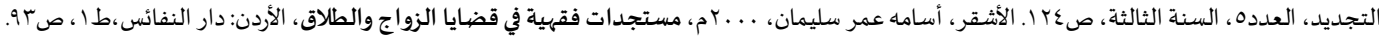

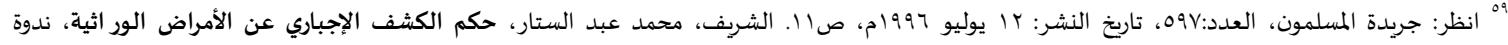

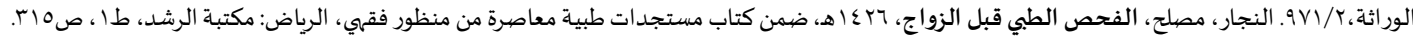

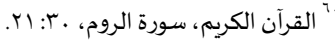

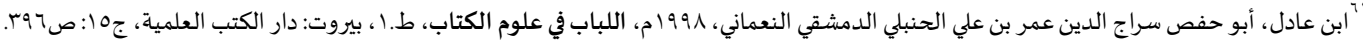


والرحماة، وكأن القرآن الكريم يوجهنا إلى آلية استمرار الحياة الزوجية بطريقة صحيحة سليمة، وأن هذا مقصد من مقاصد الشع الحنيف.

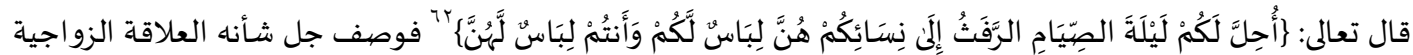

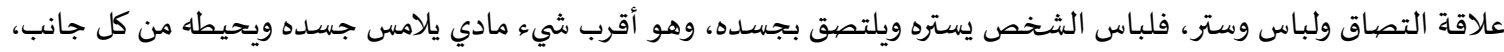

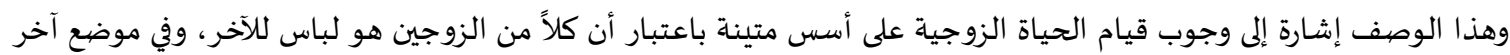

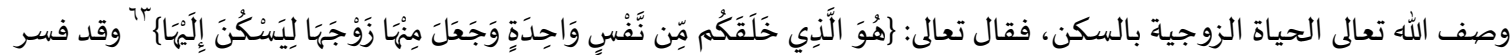

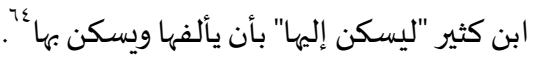

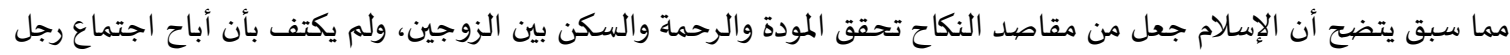

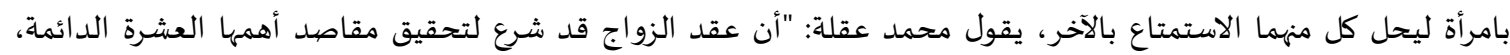

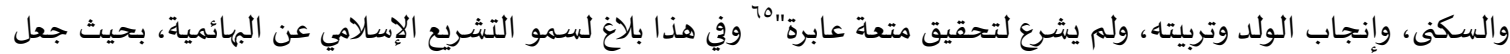

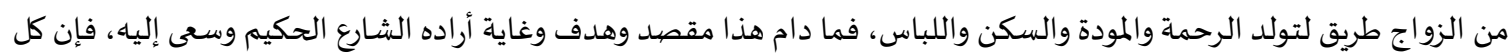

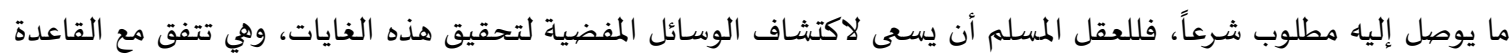

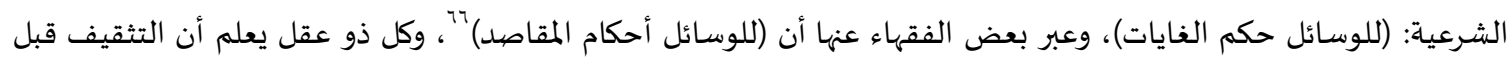

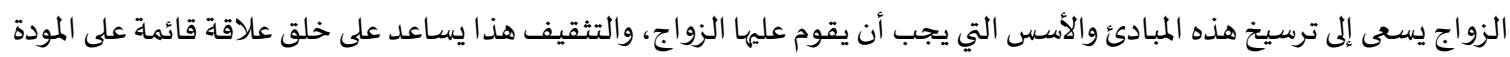

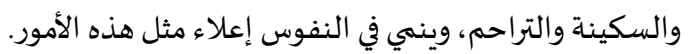

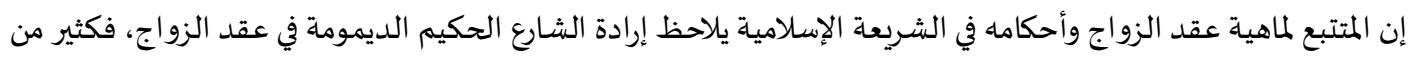

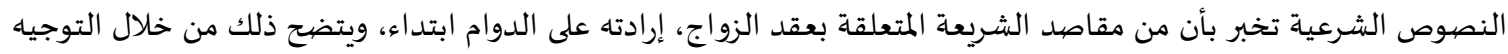

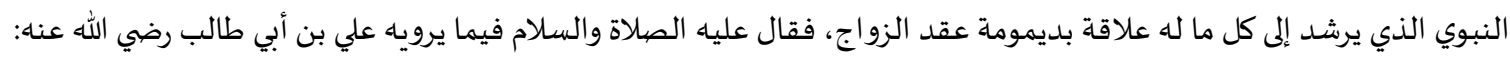

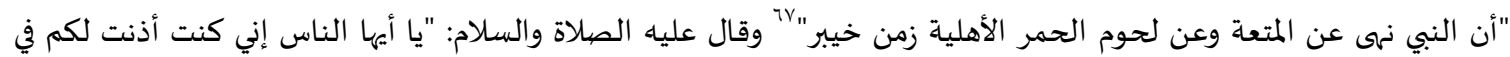

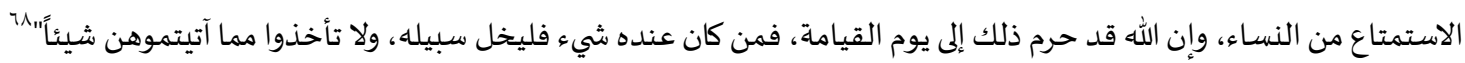

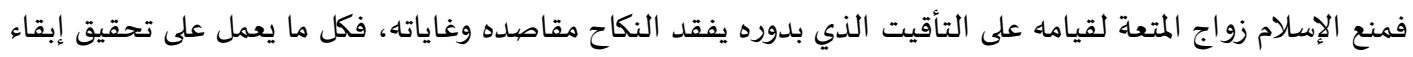

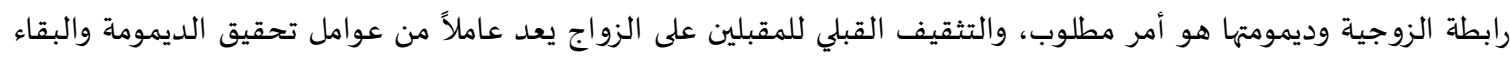
للرابطة الزوجية. إضيافة إلى ما سبق ذكره، فإن القول بجواز اشتراط الدورات التدرببية للمقبلين على الزواج، يتفق مع جملة من القواعد

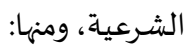

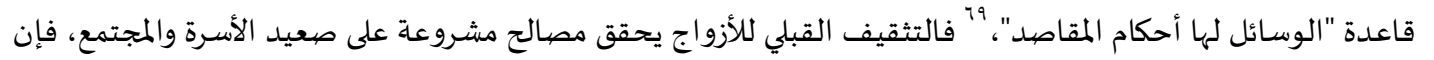

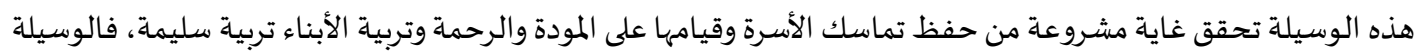

هنا تأخذ حكم الغاية.

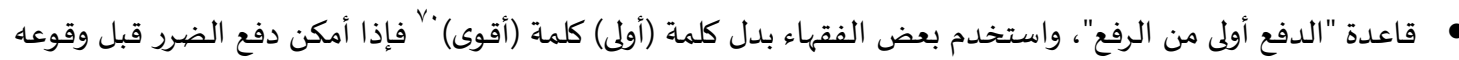

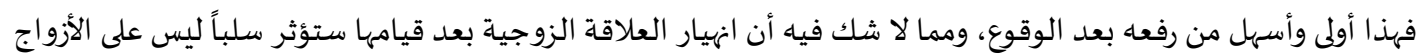

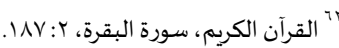

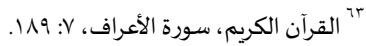

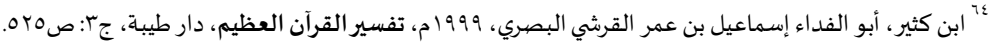

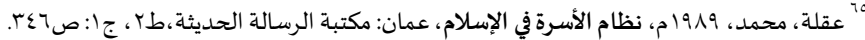

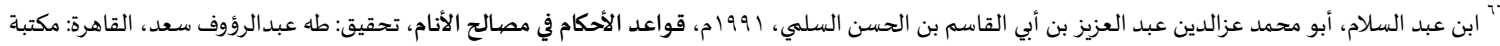

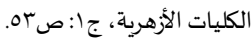

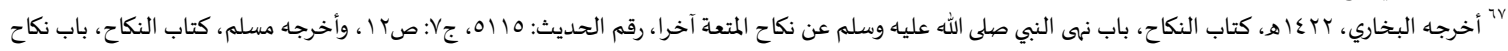

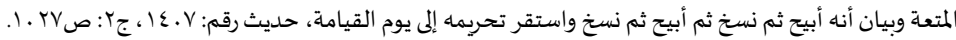

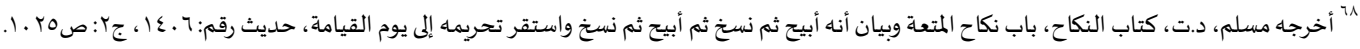

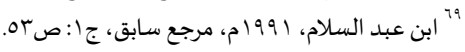

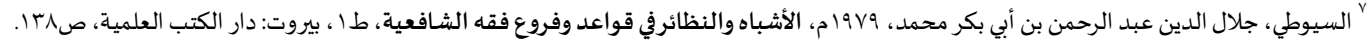


فحسب، إنما ستتعداهم إلى الأبناء وعائلة الزوجين والمجتمع ككل، وهذه الدورات التأهيلية لن تمنع الطلاق، إنما هي وسيلة للحدد منه، وتقليل آثاره حتى لو وقع، فتفادي الطلاق قبل وقوعاه، أسهل من رفعاه ورفع آثاره بعد تحققها.

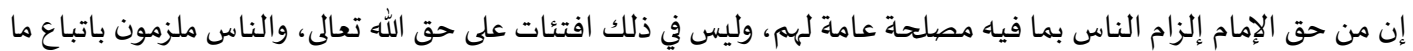
أقره الإمام المسلم، ومعلوم أن التثقيف مباح بمجمله، فإذا ما اتضح للدولة أن أحد أسباب انتشار الطلاق في المجتمع هو قلة الثقافة

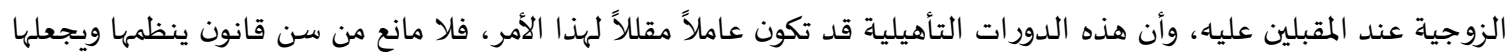
متطلباً إجباريا لإتمام عقد النكاح.

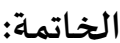

بعد الانتهاء من هذه الدراسة، فقد توصلت إلى أهم النتائج الآتية:

اهتم الإسلام بالأسرة وسعى من خلال أحكامه إلى إقامة علاقة أسرية قوية، تسودها أجواء المحبة والسكن والتفاهم،

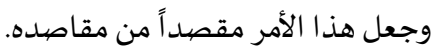

أضحت نسب الطلاق في فلسطين ملفتة ومقلقة، وهي آخذة بالازدياد بشكل مطرد، خصوصاً بين الأزواج الشابة وقبل الدخول. أسباب الطلاق في فلسطين كثير منها أسباب تقليدية، مع ظهور لاسباب جديدة تعود إلى الاستخدام غير السليم لوسائل التواصل الالكترونية.

امتلاك المقبلين على الزواج الثقافة الزوجية، ومعرفة كل منهم حقوقه وواجباته، يساهم في الحد من نسبة الطلاق. فكرة اشتراط التأهيل القبلي للمقبلين على الزواج تساهم في الحد من نسبة الطلاق، وأصبحت من الحاجة بمكان مع الارتفاع المقلق لنسب للطلاق.

اشتراط دورات تأهيلية للمقبلين على الزواج تتفق مع الشرع الحنيف، وتحقق بعضياً من مقاصيده، ولا مخالفة في إقرارها، ويمكن اسقاطها على فكرة اشتراط الفحص الطبي قبل الزواج، فكلاهما يهدف لتحقيق بعضياً من مقاصيد النكاح. اشتراط دورة تأهيلية للمقبلين على الزو اج، تكتنفه بعض المعيقات، لكن يمكن تداركها وتخطيها. ظهرت في الأونة الأخيرة العديد من الأصوات المطالبة باشتراط التأهيل القبلي للمقبلين على الزواج في البلدان العربية، ولكنها لم تترجم على أرض الواقع. التوصيات:

توصي الدراسـة ديوان قاضي القضاة في فلسطين بتشكيل لجنة علمية قانونية، للبحث في تنفيذ فكرة الدورات التأهيلية

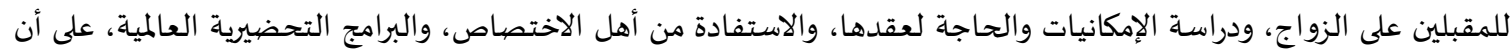

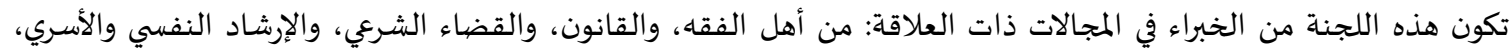
والجهات ذات العلاقة التي يمكن الاستفادة من خبرتها في هذا المجال.

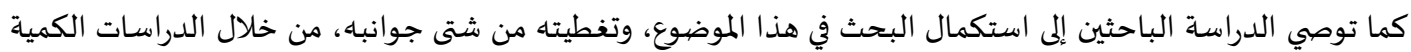

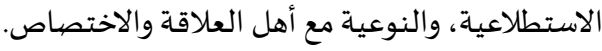

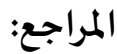

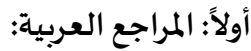

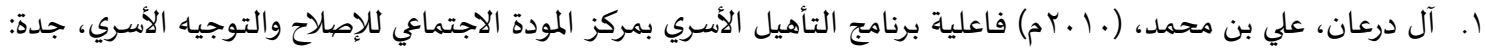
مركز المودة الاجتماعي للإصلاح والتوجياء الأسري.

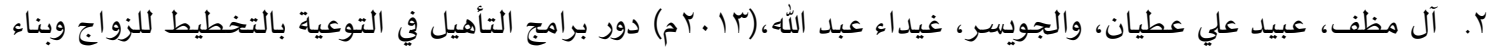
الأسرة دراسة وصفية تحليلية لبرامج التأهيل للزواج والمستفيدين منها بمدينة جدة، السعودية: مجلة جامعة الملك عبد العزيز

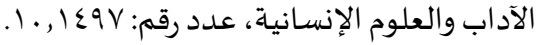

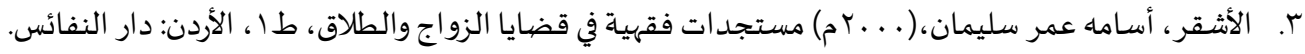

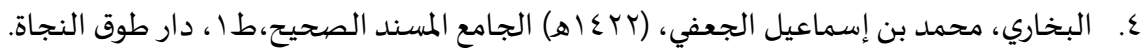

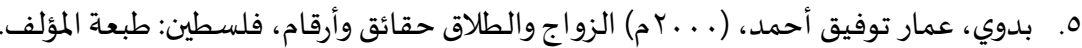


7. ابن عادل، أبو حفص سراج الدين عمر بن علي الحنبلي الدمشقي النعماني، (1991م) اللباب في علوم الكتاب، ط.ا، بيروت:

$$
\text { دار الكتب العلمية. }
$$

V. البيتاوي، حاتم حامد سليمان خضر،(1 . . Pم) التدابير الشرعية للحد من الطلاق في الفقه الإسلامي وقانون الأحوال الشخصية المعمول باه في المحاكم الشرعية الفلسطينية في القدس والضفة الغربية، فلسطين: جامعة النجاح الوطنية، رسالة

$$
\text { ماجستير في الفقه والتشريع. }
$$

A. الترمذي، أبو عيسى محمد بن عيسى بن سورة بن موسى بن الضحاك، (9V0 م) سنن الترمذي، تحقيق: أحمد شاكر ومحمد

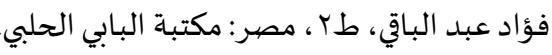

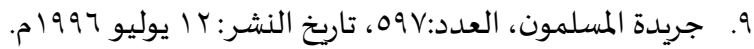

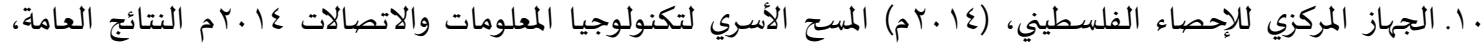
فلسطين: رام الله.

الـ الجهاز المركزي للإحصاء الفلسطيني ووزارة الاتصالات وتكنولوجيا المعلومات،(10 ـrم) تقريراً صحفياً مشتركاً بمناسبة اليوم

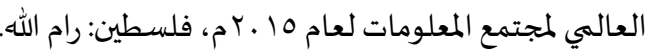

rا. الجوجو، حسن علي، (7 . .بم) التدابير الشرعية والقانونية للحد من الطلاق لدى المحاكم الشرعية في قطاع غزة، غزة:

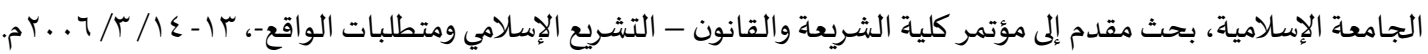

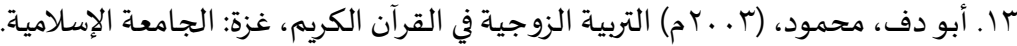

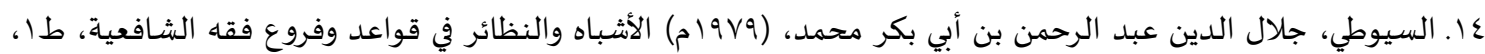
بيروت: دار الكتب العلمية.

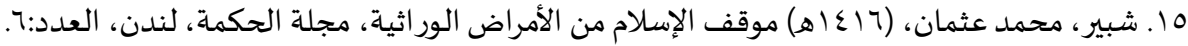
17 . الشريف، محمد عبد الستار، حكم الكشف الإجباري عن الأمراض الور اثية، ندوة الور اثلة. VI الشلتوني، أنور محمد سليمان، (1 إYم) التشريعات الممهدة للزواج وأثر تفعيلها في تمكين الأسرة، الأردن: مجلة الجامعة

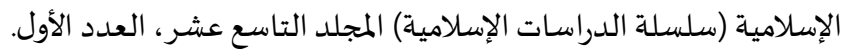
1 1. الصاوي، أبو العباس أحمد بن محمد الخلوتي، د.ت، بلغة السالك لأقرب المسالك المعروف بحاشية الصاوي على الشرح

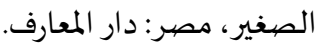

19. عارف، عارف علي، (999 19) الاختبار الجيني والوقاية من الأمراض الور اثية من منظور إسلامي، ماليزيا: مجلة التجديد، العدده، السنة الثالثة.

•r. ابن عبد السلام، أبو محمد عزالدين عبد العزيز بن أبي القاسم بن الحسن السلمي، (1991م) قواعد الأحكام في مصالح الأنام، تحقيق: طه عبد الرؤوف سعد، القاهرة: مكتبة الكليات الأزهرية.

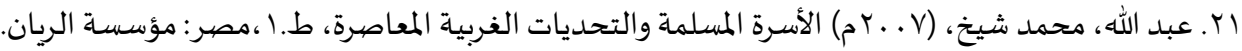
r r. ابن عسكر، منصيور بن عبد الرحمن، (د.ت)، اتجاهات الأسرة السعودية نحو الدورات التدرببية في العلاقات الزوجياة، السعودية: مشروع ابن باز الخيري لمساعدة الشباب على الزواج، مركز المعلومات وأبحاث الأسرة.

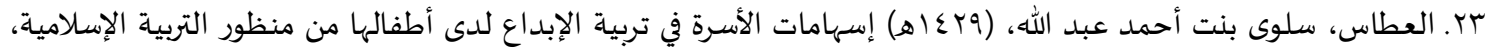

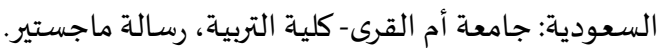

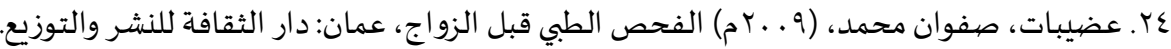

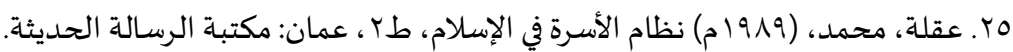

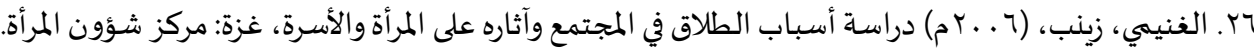

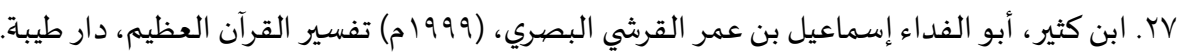

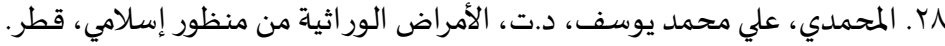

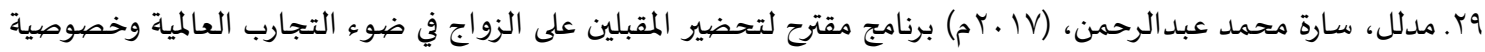

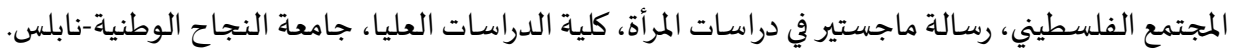

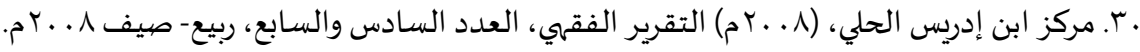


آ. المرزوقي، حسن محمد، (عا ـ rم) الفحص الطبي قبل الزواج في الشريعة والقانون الإماراتي وفق القواعد الشرعية، جامعة

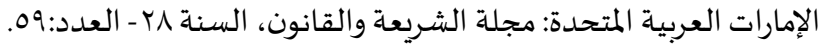

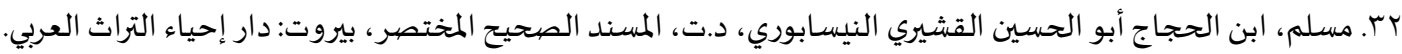
rr. النجار، مصلح، (7rع اهه) الفحص الطبي قبل الزواج، ضمن كتاب مستجدات طبية معاصرة من منظور فقهي، ط ال، الرياض: مكتبة الرشد.

ع ب. ابن الهمام، كمال الدين محمد بن عبد الواحد السيواسي، د.ت، فتح القدير، بيروت: دار الفكر. 0r. وزارة الاتصالات وتكنولوجيا المعلومات، (10 ـrم) ملخص وأرقام حول مجتمع المعلومات الفلسطيني عـا ـr م، فلسطين: رام الله.

حب. وزارة العدل السعودية، التقرير الإحصيائي للزواج والطلاق لعام بحـا ه، المملكة العربية السعودية: دائرة الإحصاء.

ثانياً: المراجع الالكترونية:

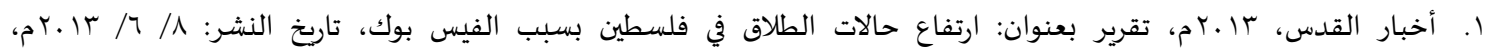
http://www.imcpal.ps/news/?p=2033

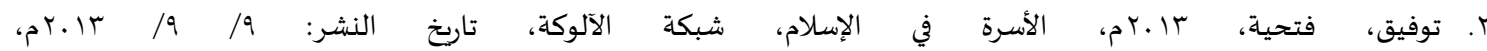
http://www.alukah.net/sharia/0/59694/\#ixzz3zjYL4X7w r. الجهاز http://www.pcbs.gov.ps/Portals/_Rainbow/Documents/VS-2016-08a.htm ء. الجوجو، حسن علي، 10 •rم، الطلاق بين حديثي الزواج أسباب وحلول، الصفحة الرسمية للمجلس الأعلى للقضاء الشرعي، تاريخ

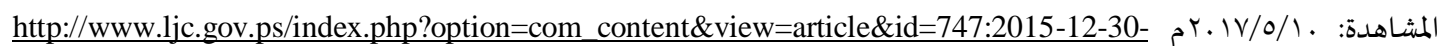

11-53-07\&catid=19:2010-01-18-08-34-22

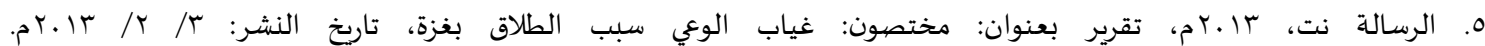
http://alresalah.ps/ar/index.php?act=post\&id=84027

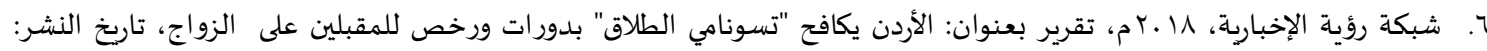

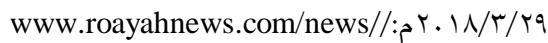

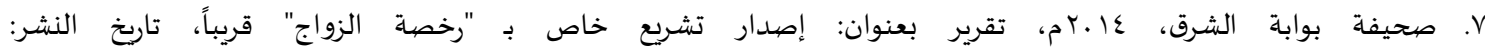

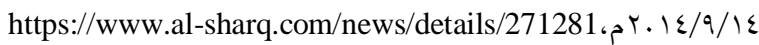
^. صحيفة القدس العربي، عا ـrم، تقرير صحفي، الفلسطينيون يحملون 'فيسبوك' مسؤولية تصاعد نسبة الطلاق في صفوفهه، تقرير

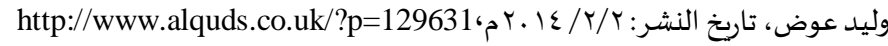

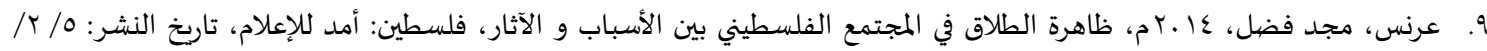

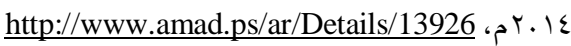

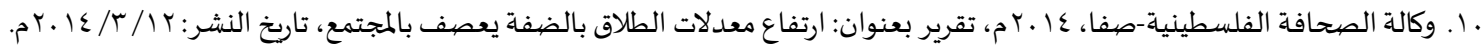
http://cutt.us/8gkUh 1". وكالة

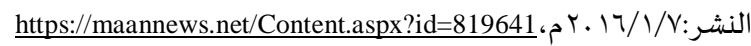

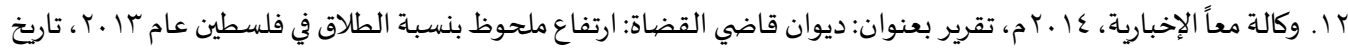

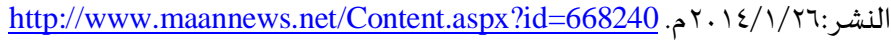


Refaad

رفاد للدراسات والأبحاث

www.refaad.com
المجلة الدولية للدراسات الإسلامية المتخصصية

e-ISSN 2617-6246, p-ISSN 2617-6238

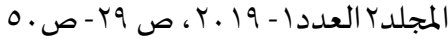

ttps://doi.org/DOI:10.31559/sis2019.2.1.2

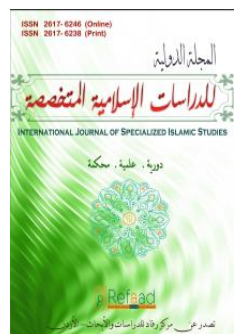

\title{
Requirements for a Training Course for those who are Intending to Marriage in Palestine: Legitimacy and Need
}

\author{
Yousef A.H Keleibi
}

Assistant Professor in the Department of Sharia Jurisdiction- Faculty of Islamic Da'wah- Qalqilia yoseufk@hotmail.com

\begin{abstract}
Islam took care of the family and marriage, raised their importance, and proceeded to preserve them. Also Islam put a way for annulment of this marriage. Nowadays we are suffering from the loss of the meanings of the sanctity of married life in the hearts of some couples; until the divorce become an easy action for them, and the divorce rate became disturbing and increasing significantly. It is worth looking for practical ways and means to reduce the rising divorce rate which is the study problem. The importance of the study stems from the search for a proposed practical means to reduce the high divorce rates, namely, mandatory education for those who intended to marry and before their marriage. This study aims to explain the Islamic philosophy for family and marriage, to review the importance and need for such education and its role in reducing the divorce rate, as well as to clarify the legitimacy of the requirement of such courses for those who intending to marry. The researcher followed the inductive and analytical descriptive approach in his study. The study concluded that the interest of Islam in the family and the establishment of a healthy married life is the basis of love, understanding and permanence which is one of the purposes of Islamic beliefs. In addition to that, there is an urgent need for mandatory education for those who intending to marry, which contributes to reduce the divorce rate and marital disputes. Also, the requirement of a mandatory course is legitimate and fulfills some of the objectives of the Islamic Shar'i.
\end{abstract}

Keywords: Marriage, Divorce, training, Qualification, Palestine.

\section{References:}

[1] 'ạrf. 'ạrf 'ly, Ạlạkḥtbạr Aljyny Wạlwqạyh Mn Alạ̉mrạạ Ạlwrạthnyh Mn Mnzwr ẠSlạmy, Mạlyzyạ: Mjlï Ạltjdyd, Ạl'dd5, Ạlsnh Ạlthạalth̄h, (1999)

[2] 'bd Ạllh, Mḥmd Shbykḥ, Ạlạ̉srh Ạlmslmh Wạltḥdyạt Ạlgḥhrbyh Ạlm'ạṣrh, Ṭ.1,Mṣr: Mw̉ssï Ạlryạn, (2007m)

[3] 'ḍybạt. Șfwạn Mḥmd, Ạlfḥs Ạlṭby Qbl Ạlzwạj, 'mạn: Dạr Ạltḥqạft Llnsḥhr Wạltwzy', $(2009 \mathrm{~m})$

[4] 'qlh. Mḥmd, Nzạam Ạlạ̉srẗ Fy Ạlạslạm, Ṭ2, 'mạn: Mktbë Ạlrsạlh Ạlḥ̣dytḥh, (1989m)

[5] Ạbn 'ạdl. Ạ̉bw Ḥfṣ Srạj Ạldyn 'mr Bn 'ly Ạlḥnbly Ạldmshnqy Ạln 'mạny, Ạllbạb Fy 'lwm Ạlktạb, Ț.1, Byrwt: Dạr Ạlktb Ạl'lmyh, (1998m)

[6] Ạbn 'bd Ạlslạm. Ạ̉bw Mḥmd 'zạldyn 'bd Ạl'zyz Bn Ạ̉by Ạlqạsm Bn Ạlḥsn Ạlslmy, Qwạ 'd Ạlạ̉ḥkạm Fy Mṣạlḥ Ạlạ̉nạm, Tḥqyq: Ṭh 'bd Ạlrw̉wf S'd, Ạlqạhrh: Mktbể Ạlklyạt Ạlạ̉zhryh, (1991m) 
[7] Abn 'skr. Mnșwr Bn 'bd Alrḥmn, (D.T), Atjạạa Alạ̉srh Als'wdyh Nhw Aldwrạt Altdrybyh

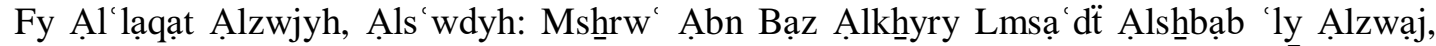
Mrkz Ạlm lwmạt Wạ̉bhạath Ạlạ̉srh.

[8] Ạbn Ạlhmạm. Kmạl Ạldyn Mḥmd Bn 'bd Ạlwạhd Ạlsywạsy, D.T, Ftḥ Ạlqdyr, Byrwt: Dạr Alfkr.

[9] Ạbn Kthnyr. Ạ̉bw Ạlfdạ’ ẠSmạ yl Bn 'mr Ạlqrshny Ạlbṣry, Tfsyr Ạlqrận Ạl'zym, Dạr Ṭbbh, (1999m)

[10] Ạ̉bw Df. Mḥmwd, Ạltrbyh Ạlzwjyh Fy Ạlqrận Ạlkrym, Ghnzh: Ạljạm h Ạlạisạmyh, (2003m)

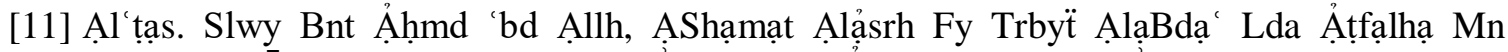

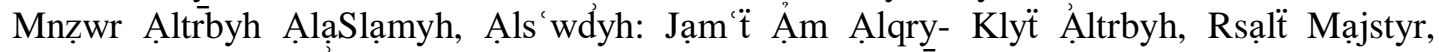
(1429h)

[12] Ạlạ̉shoqr. Ạ̉sạmh 'mr Slymạn, Mstjdạt Fqhyh Fy Qḍayạ Ạlzwạj Wạlțlạq, Ṭ1, Ạlạ̉rdn: Dạr Ạlnfạys, (2000m)

[13] Ạlbkhạry. Mḥmd Bn Ạ̦Smạ yl Ạlj fy, Ạljạm` Ạlmsnd Ạlșḥyḥ̣,Ṭ1, Dạr Țwq Ạlnjạh, (1422h)

[14] Ạlbytạwy. Hạtm Hạmd Slymạn Kḥḍ, Ạltdạbyr Ạlsḥr yh Llhọd Mn Ạlțlạq Fy Ạlfqh

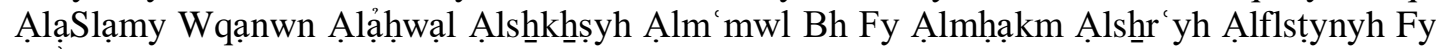
Ạlqds Wạlḍft Ạlghrbyh, Flsțyn: Jạm đạ Ạlnjạh Ạlwṭnyh, Rsạlẗ Mạjstyr Fy Ạlfqh Wạltsh̆ry’, (2001m)

[15] Ậl Dr'ạn. 'ly Bn Mhmd, Fạ lyë Brnạmj Ạltạ̉hyl Ạlạ̉sry Bmrkz Ạlmwdh Ạlạjtmạ y Llậ̣lạh Wạltwjyh Ạlạ̉sry, Jdît: Mrkz Ạlmwdh Ạlạjtmạ y Llậ̣lạ̣ Wạltwjyh Ạlạ̉sry, (2010m)

[16] Alghnnymy. Zynb, Drạsẗ Ảsbạb Ạlțlạq Fy Ạlmjtm' Wậthạrh 'ly Ạlmrạ̉h Wạalạsrh, Ghzzh: Mrkz Shỉwwn Ạlmrạ̉h, (2006m)

[17] Aljhạz Aalmrkzy Llạ̣Hṣạ Alflsțyny, Almsh Ạlạ̉sry Ltknwlwjyạ Ạlm lwmạt Wạlạtșạlạt 2014m Ạlntạyj Ạl ạmh, Flsṭn: Rạm Ạllh, (2014m)

[18] Aljhạz Almrkzy LlạHṣạa Alflsṭyny Wwzạrẗ Alạtṣạạt Wtknwlwjyạa Ạlm lwmạt, Tqryrạan

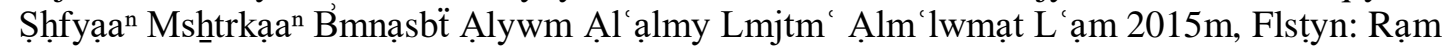
Ạllh, (2015m)

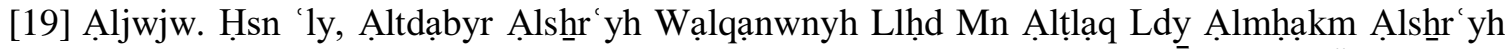

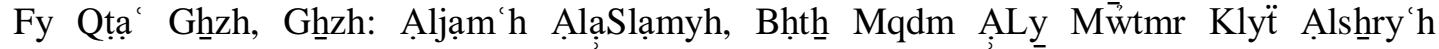
Wạlqạnwn - Ạltsḩry` ẠlạjSlạmy Wmtṭlbạt Ạlwạq'-, 13- 14/ 3, (2006m)

[20] Ạlmḥmdy. 'ly Mḥmd Ywsf, D.T, Ạlạ̉mrạ̣ Ạlwrạthַyhh Mn Mnẓwr ẠSlạmy, Qṭr.

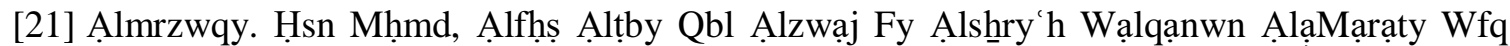

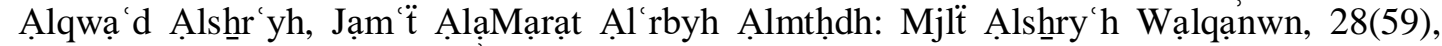
(2014m)

[22] Ậl Mẓf. 'byd 'ly 'țạn, Wạljwysr, Ghyydạ' 'bd Ạllh, Dwr Brạmj Ạltạ̉hyl Fy Ạltw'yh Bạltkhțtyt Llzwạj Wbnạ' Ạlạ̉srh Drạsh Wṣfyh Thlylyh Lbrạmj Ạltạ̉hyl Llzwạj Wạlmstfydyn

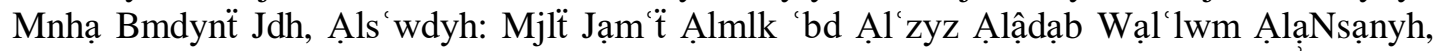
(10.1497), (2013m) 
[23] Allnjạr. Mṣlḥ, Ạlfḥs Ạlṭby Qbl Ạlzwạj, Dmn Ktạb Mstjdạt Ṭbyh M'ạșrh Mn Mnẓwr Fqhy, Ṭ1, Ạlryạḍ: Mktbë Ạlrshdd, (1426h)

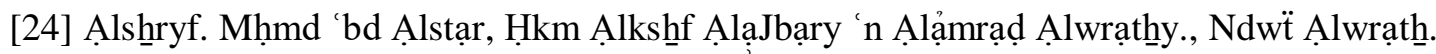

[25] Ạlsh̆ltwny, Ạ̉nwr Mḥmd Slymạn, Ạltsḩry’ạt Ạlmmhdh Llzwạj Wạ̉tḥr Tf́ylhạ Fy Tmkyn Ạlạ̉srh, Ạlặrdn: Mjlï Ạljạm'h Ạlạ̧Slạmyh (Slslï Ạldrạsạt Ạlạ̧Slạmyh) Ạlmjld Ạltạs' 'shorr, Ạl'dd Ạlậwl, (2011m)

[26] Ạlṣạwy. Ạ̉bw Ạl bạs Ạ̉ḥmd Bn Mḥmd Ạlkhllwty, D.T, Blgḥt Ạlsạlk Lặqrb Ạlmsạlk Ạlm rwf Bhạshhyë Ạlṣawy 'la Ạlsḥrḥ Ạlṣghnyr, Mṣr: Dạr Ạlm ạ̣rf.

[27] Ạlsywṭy. Jlạl Ạldyn 'bd Ạlrḥmn Bn Ạ̉by Bkr Mḥmd, Ạlạ̉sḥbạh Wạlnẓạ̉r Fy Qwạ 'd Wfrw' Fqh Ạlshạf'yh, Ṭ1, Byrwt: Dạr Ạlktb Ạl 'lmyh, (1979m)

[28] Âltrmdhyy. Ạ̉bw 'ysy Mḥmd Bn 'ysy Bn Swrh Bn Mwsy Bn Ạlḍhạk, Snn Ạltrmdhny, Tḥqyq:

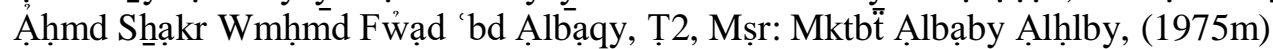

[29] Bdwy, 'mạr Twfyq Ạhmmd, Ạlzwạj Wạlțlạq Ḥậ̉q Wạ̉rqạm, Flsṭn: Ṭb ‘̈ Ạlmw̉lf, (2000m)

[30] Jrydë Ạlmslmwn, Ạl'dd:597, Tạrykh Ạlnsḥr: 12 Ywlyw (1996m).

[31] Mdll. Sạrh Mḥmd 'bdạlrḥmn, Brnạmj Mqtrḥ Ltḥ̣yr Ạlmqblyn 'la Ạlzwạj Fy Dwo Ạltjạrb Ạl'ạlmyh Wkḥșwṣyh Ạlmjtm Alflsțyny, Rsạlt Mạjstyr Fy Drạsạt Ạlmrạ̉h, Klyë Ạldrạsạt Ạl' lyạ, Jạm ‘̈ Ạlnjạh Ạlwțnyh-Nạbls, (2017m)

[32] Mrkz Ạbn ẠDrys Ạlḷly, Ạltqryr Ạlfqhy, Ạl‘dd Ạlsạds Wạlsạb', Rby'- Ṣyf, (2008m).

[33] Mslm. Ạbn Ạlḥjạj Ạ̉bw Ạlḥsyn Ạlqshhyry Ạlnysạbwry, D.T, Ạlmsnd Ạlṣḥ̣ḥ̣ Ạlmkḥtṣr, Byrwt: Dạr ẠHyạ’ Ạltrạth Ạl'rby.

[34] Shbbyr. Mḥmd 'tḥmạn, Mwqf ẠlạSlạm Mn Ạlạ̉mrạ̣ Ạlwrạtḥyh, Mjlë Ạlḥkmh, Lndn, (6)(1416h)

[35] Wzạrẗ Ạlạtșạlạt Wtknwlwjyạ Ạlm lwmạt, Mlkḥs Wạ̉rqạm Ḥwl Mjtm Ạlm lwmạt Ạlflsțyny 2014m, Flsṭn: Rạm Ạllh, (2015m)

[36] Wzạrẗ Ạl'dl Ạls'wdyh, Ạltqryr Ạlạhṣạyy Llzwạj Wạlțlạq L'ạm 1463h, Ạlmmlkh Ạl'rbyh Ạls 'wdyh: Dậ̉r̆ Ạlạhṣạ’. 